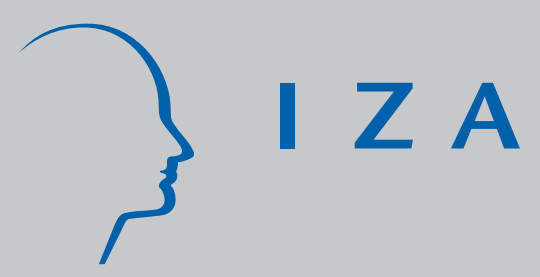

IZA DP No. 613

Internet J ob Search and Unemployment Durations

Peter Kuhn

Mikal Skuterud

October 2002 


\title{
Internet Job Search and Unemployment Durations
}

\author{
Peter Kuhn \\ University of California, Santa Barbara \\ and IZA Bonn
}

Mikal Skuterud

Statistics Canada, Ottawa

\section{Discussion Paper No. 613 October 2002}

\author{
IZA \\ P.O. Box 7240 \\ D-53072 Bonn \\ Germany \\ Tel.: +49-228-3894-0 \\ Fax: +49-228-3894-210 \\ Email: iza@iza.org
}

This Discussion Paper is issued within the framework of IZA's research area The Future of Labor. Any opinions expressed here are those of the author(s) and not those of the institute. Research disseminated by IZA may include views on policy, but the institute itself takes no institutional policy positions.

The Institute for the Study of Labor (IZA) in Bonn is a local and virtual international research center and a place of communication between science, politics and business. IZA is an independent, nonprofit limited liability company (Gesellschaft mit beschränkter Haftung) supported by the Deutsche Post AG. The center is associated with the University of Bonn and offers a stimulating research environment through its research networks, research support, and visitors and doctoral programs. IZA engages in (i) original and internationally competitive research in all fields of labor economics, (ii) development of policy concepts, and (iii) dissemination of research results and concepts to the interested public. The current research program deals with (1) mobility and flexibility of labor, (2) internationalization of labor markets, (3) welfare state and labor market, (4) labor markets in transition countries, (5) the future of labor, (6) evaluation of labor market policies and projects and (7) general labor economics.

IZA Discussion Papers often represent preliminary work and are circulated to encourage discussion. Citation of such a paper should account for its provisional character. A revised version may be available on the IZA website (www.iza.org) or directly from the author. 
IZA Discussion Paper No. 613

October 2002

\section{ABSTRACT}

\section{Internet Job Search and Unemployment Durations}

After decades of stability, the technologies used by workers to locate new jobs began to change rapidly with the diffusion of internet access in the late 1990's. Which types of persons incorporated the internet into their job search strategy, and did searching for work on line help these workers find new jobs faster? We address these questions using measures of internet job search derived from the December 1998 and August 2000 CPS Computer and Internet Supplements, matched with job search outcomes from subsequent CPS files. We find that internet searchers are positively selected on observables, but negatively selected on unobservables. A beneficial (unemployment-duration reducing) causal effect of internet job search is consistent with our estimates only if negative selection on unobservables is especially strong, in other words only if the population of on-line resumes is strongly adversely selected.

JEL Classification: J64

Keywords: $\quad$ unemployment, duration, hazard models, internet, job search

Corresponding author:

Peter Kuhn

Department of Economics

University of California

Santa Barbara CA 93106

USA

Tel.: +1 8058933666

Fax: +1 8058938830

Email: pjkuhn@econ.ucsb.edu 
"Using CareerBuilder ${ }^{\circledR}$ to find a job is like driving in the carpool lane."

-half-page ad for an internet job site in the Los Angeles Times, Friday March 1, 2002. (p.

C5)

"Think Monster for the best resumes, the best candidates."

-Monster.com web site, Sept. 19, 2002.

\section{Introduction}

After decades of stability, the technologies used by workers to locate new jobs began to change rapidly with the diffusion of internet access in the late 1990's. As early as August 2000, one in four unemployed U.S. jobseekers reported that they regularly used the internet to look for jobs; one in ten employed persons said they regularly looked for other jobs on line. The use of internet job and recruiting sites is generally free of cost for workers and much cheaper for firms than traditional print advertisements. In addition, these services offer firms and workers the promise of instant access to a much larger number of possible matches than traditional channels, as well as the potential for the exchange of much more detailed information about both worker and job attributes.

Not surprisingly, economists have begun to speculate on the potential effects of the above developments on labor markets. For example, commentators have argued that the higher contact rate, lower cost, and greater information content provided by this technology could lead to lower frictional unemployment (Mortensen 2000), higher average match quality (Krueger 2000), a reduction of noncompetitive wage differentials (Autor 2001), and an amplification of ability-related wage differentials (Kuhn 2000). If

\footnotetext{
${ }^{1}$ For example, at firms' request WebHire will check the following worker credentials: social security numbers; current and previous addresses; references; education; criminal, civil and bankruptcy court records; driving and credit reports; and workers' compensation claims. Also offered are on-line skills and personality testing. The combination of internet application procedures and traditional database management software also dramatically simplifies the process of searching through submitted resumes for appropriate matches. Finally, workers can now gain much more information about working conditions and job requirements from job boards as well as company websites.
} 
even some of these claims are correct, the advent of internet job search will have important implications for both labor- and macroeconomic policy. ․․

This article has two main goals, the first of which is to understand the process by which jobseekers choose to use internet methods to look for work. Second, we aim to estimate the causal effect, for an individual worker, of incorporating the internet into his or her job search strategy. We are of course well aware that, even if internet search has private, individual benefits, it does not follow that the equilibrium effects of introducing this technology on unemployment rates, wages and other outcomes are socially beneficial. However, since in most equilibrium models, some "first-order", or private effects are a necessary condition for any general equilibrium effect to occur, the questions posed in this paper seem to be the right ones to ask first.

In order to answer our questions we use measures of internet search derived from the December 1998 and August 2000 CPS Computer and Internet Use Supplements, matched with job search outcomes from all subsequent CPS files that contain some of the same survey respondents. Throughout our analysis we focus on the search methods and outcomes of unemployed persons only. This is because the regular monthly CPS does not collect data on non-internet job search by employed persons. ${ }^{-1}$ Thus, for those with jobs, CPS data does not allow one to distinguish internet job search activity from the decision to look for work at all. We also restrict our attention to one particular outcome of the job search process - jobless duration. In part, this is driven by data considerations: in the CPS, job quality (i.e. wage) information is not available for a sufficient sample of

\footnotetext{
${ }^{2}$ One potentially relevant aspect of labor market policy is the rationale for government-provided job matching services such as the states' Employment Services. Macro policy implications could follow from any change in the natural unemployment rate caused by internet job search technology.

${ }^{3}$ For example, Lang (2000) has suggested an asymmetric-information model in which a reduction in the costs of applying to jobs can be Pareto-worsening, in part by reducing the average match quality in every firm's applicant pool.
} 
jobseekers. ${ }^{\text {G }}$ For many policy purposes, however, unemployment durations are the outcome of most direct interest, justifying our focus here.

This paper contributes to an emerging literature on the effects of internet technology on product market performance (e.g. Brown and Goolsbee 2002 in life insurance markets; Brynjolfsson and Smith 2000 on book and CD markets, and Carlton and Chevalier 2001 on various consumer goods); to our knowledge ours is the only study of the effects of internet technology on the functioning of the labor market. The current paper also contributes to an older literature on the relative effectiveness of different job search methods. For example, Holzer (1987, 1988), Bortnick and Ports (1992), Osberg (1993) and Addison and Portugal (2001) compare the job-finding rates of unemployed workers using a variety of search methods. Thomas (1997) focuses specifically on the effectiveness of public employment agencies. Finally our work also relates to a recent literature on the "digital divide", which asks whether differential access to computer or internet technology aggravates inequality along various dimensions (e.g. Fairlie 2001); as we discuss below, at least some of our results regarding selection into internet job search are surprising in the light of this literature.

In our data, simple means indicate that internet job searchers are more likely to be employed one year after their search methods are observed than are other unemployed workers. However it is also the case that internet job searchers are better-educated, previously worked in occupations with lower unemployment rates, and had several other characteristics which are generally associated with shorter unemployment durations in our sample as well as others. Once these observable differences are held constant, we

\footnotetext{
${ }^{4}$ See Skuterud (2001) for a recent analysis of trends in on-the-job search using the occasional CPS surveys that do collect this information.
} 
find no difference in employment rates twelve months later. Further adjusting our estimates (a) to incorporate all the available information in our sample on unemployment durations, and (b) for length-biased sampling (Lancaster 1979), yields estimated internet job search effects that are counterproductive, i.e. internet job search appears to lengthen unemployment spells.

Finally, we develop and add to the above model an instrumental-variables-type technique to adjust for endogenous selection into internet search on unobservables. To our knowledge this is the first application to simultaneously model selection into a treatment (internet search) and the effects of the treatment in a duration model, allowing for a continuous joint distribution of the unobservables in the two equations. ${ }^{6}$ While this model cannot unequivocally rule out a beneficial causal effect of internet job search on unemployment durations, it does imply --using a zero effect of internet search as a lower bound on the true effect-- a statistically significant level of negative selection on unobservables; in other words, internet job searchers are less likely than observationallyidentical unemployed workers to be re-employed regardless of the search methods they use. As a consequence, a significant beneficial effect of internet search would be consistent with our data only if selection into internet search were even more negative than this "baseline" level. Internet search firms who simultaneously claim to employers that their applicants are positively selected (on hard-to-document characteristics) and to their applicants that internet search will reduce their search time are therefore making claims that are inconsistent with our evidence.

\footnotetext{
${ }^{5}$ CPS wage information is of course only available for persons who find new jobs, and who are in the outgoing rotation groups. Further, a credible analysis of re-employment wages also requires controls for pre-unemployment wages, a restriction which reduces the sample to non-useful levels.

${ }^{6}$ Heckman and Singer's (1984) approach would be to model unobserved heterogeneity in both the unemployment and search equations as a discrete bivariate distribution. In practice, this typically amounts to allowing each of the error terms to take two distinct values only.
} 


\section{Data and Descriptive Statistics}

As noted, our data on internet job search come from the December 1998 and August 2000 Computer and Internet Use Supplements to the Current Population Survey. These supplements included the following question: "Do(es) (you) (any one) REGULARLY use the Internet ... to search for jobs?”. As always, the regular monthly CPS survey in these months also asked unemployed individuals which out of a list of nine "traditional" job search methods they used.

Internet job search rates in these two surveys, classified by labor force status, are shown in Table 1. As already noted, the fraction of unemployed jobseekers looking for work on line was 25.5 percent in August 2000, up from 15.0 percent in November 1998, less than two years earlier. As Table 1 also shows, much of this increase was associated with a large rise in home internet access among unemployed persons (from 22.3 to 39.4 percent), but internet use for job search conditional on internet access also rose over this period. By August 2000, regular internet job search was also surprisingly common among the employed (around 11 percent) and among labor force nonparticipants, at least those who were neither retired nor disabled (around 6 percent).

In order to measure the job-finding success of internet versus other job searchers, we matched observations in the December 1998 supplement with the same persons in the ten subsequent CPS regular monthly surveys (January-March 1999, September 1999 through March 2000) in which some of the same individuals were re-interviewed. Similarly the August 2000 survey was matched with September-November 2000, and

\footnotetext{
${ }^{7}$ All unemployed workers not expecting to be recalled to their former employer are classified by the BLS as "jobseekers".
} 
May through November 2001. Matching was done using established methods (see for example Madrian and Lefgren 1999); some details about our procedure are provided in Appendix A.

To be in our sample, a person had to be unemployed according to the official Bureau of Labor Statistics definition in a Computer/Internet supplement month (December 1998 or August 2000), yielding a sample of 4139 persons. ${ }^{9}$ To be considered unemployed, the individual had to be not working, and either "on layoff" from a job to which he/she expected to be recalled, or searching for work using at least one of nine recognized "active" methods. 10 These methods are listed in Table 2; note that they could themselves involve internet use (for example "sending resumes" could include sending resumes via email). The role of our internet supplement variable is to distinguish persons who incorporated the internet into their job search strategy from those who did not, holding other dimensions of this strategy fixed.

Sample means of all the variables used in the regression analyses below are presented in Table 2 separately for unemployed persons who searched for a new job on the internet and those who did not. In most cases, unemployed workers who look for jobs on line have observable characteristics that are usually associated with greater job search success than other unemployed workers. For example, in the Computer/Internet Supplement month, the average unemployed internet searcher had already been unemployed for 3.44 months, somewhat less than the 3.75-month "retrospective

\footnotetext{
${ }^{8}$ Kuhn and Skuterud (2000) compare these recent rates of on-the-job internet job search (IJS) to historical measures of on-the-job search (OJS) via any method. They are siginficantly higher, suggesting that the internet may have contributed to an increase in total OJS.

${ }^{9}$ This includes a small group of persons who were never matched with an observation after those dates. While these observations contribute no information on unemployment durations, they do contribute information on the determinants of internet search, and are retained in our analysis for that reason.
} 
duration" of the non-internet searchers. Internet searchers resided in states with somewhat lower unemployment rates than other unemployed workers, and had previously worked in occupations with considerably lower unemployment rates. They were more likely to have been employed prior to the current unemployment spell, were much better educated, and were more likely to be in their "prime" working ages (26-55) (versus under 26 or over 55). Internet job searchers were less likely to be black, Hispanic or immigrant and more likely to be homeowners than other unemployed persons. Finally, on average, unemployed workers who looked for work on line were more likely, not less likely, to use "traditional" job search methods than other unemployed workers. In all, they used an average of 2.17 "traditional" search methods, compared to 1.67 for other unemployed workers, suggesting an overall greater investment in search. 1

Table 2 also reports rates of internet use outside the home among the members of respondents' households. These rates differ between internet job searchers and others, with the spouses and "other" household members (excluding spouses, parents and chilldren) of internet job searchers being more likely to use the internet outside the home. Finally, Table 2 shows that internet job searchers live in states with higher mean overall internet access rates, and where a smaller share of households must make a long-distance call to access the internet. There is no significant difference in state mean internet access fees between internet searchers and other unemployed persons.

By construction, no one in our sample was working in the month in which we observe whether or not their job search strategy incorporated the internet (December 1998 or August 2000). The fraction of our sample observed in employment at various

\footnotetext{
${ }^{10}$ We also conducted some analyses that excluded workers expecting recall, as well as some analyses that included marginally-attached workers (nonparticipants who engaged in passive job search only). In neither case were the results substantially different.
} 
points after these dates is reported in Table 3. For example, among those individuals whose labor market status was observed one month after the Supplement date (i.e. in January 1999 or September 2000), 29.1 percent were employed. Two months after the supplement date, 37.5 percent were employed, and a year later 55.9 percent were employed. If we pool all individuals who were re-interviewed at least once after the date in which we observe their internet search activity, the same share, 55.9 percent, were seen in re-employment at some time after the Supplement date.

Comparing internet job searchers with other unemployed workers, essentially no difference in employment rates is evident one or two months after an individual's internet job search activity is observed. A year later, however, 64.6 percent of unemployed internet searchers are re-employed, compared to 53.3 percent of other unemployed workers. This difference, like the difference in re-employment at any time after the Supplement date (in row 4 of the Table), is statistically significant. On the surface, Table 3 thus seems to suggest that internet search facilitates re-employment, at least if one allows a few months to elapse for this method to yield results.

\section{Re-employment Probits}

A first step in ascertaining whether the differences found in Table 3 are truly causal effects of internet search is to see whether they are simply artifacts of differences between internet searchers and other unemployed persons in observable characteristics, such as education, local labor market conditions, and the use of non-internet job search methods. To this end, Table 4 presents probit estimates of the probability an unemployed individual is re-employed 12 months after we observe their internet job search activity in

\footnotetext{
11 This apparent "complementarity" between internet and other job search methods is examined in more detail in Kuhn and Skuterud (2000).
} 
the CPS Computer/Internet Supplement. We focus on 12 months because this is where the largest apparent internet effect was observed in Table 3.12

Of course, re-employment probabilities in the above probits will likely depend on how long an individual had already been unemployed when we observe whether or not he/she uses the internet for job search, i.e. at the Supplement date. As is well known, there are at least two distinct reasons for this: duration dependence (long unemployment spells may have a causal effect on subsequent exit rates from unemployment), and unobserved heterogeneity (individuals who have been unemployed a long time are disproportionately less "employable" on unobserved dimensions). In Sections 3-5 of this paper we handle both these possibilities in a simplistic manner: we simply include "retrospective" (pre-Supplement date) unemployment durations as a regressor in our models of post-Supplement durations. Sections 6 and 7 will handle both these issues more formally.

Throughout Table 3 as well as all the following tables, we will present specifications of each equation with and without a control for home internet access. While we do not believe home internet access has a causal effect on the job-finding rate -what should matter is whether the internet is used for job search-we can think of plausible arguments both for and against holding it constant in a comparison of internet searchers and others. On the "for" side, home internet access may be correlated with other unobserved characteristics (for example wealth, which in turn is correlated with past employment) that do affect job-finding rates. On the other hand, home internet

\footnotetext{
${ }^{12}$ Similar analyses were performed for re-employment within a month, within two months, or at any time after internet search activity is observed. (In the latter specification, we added a control for the number of months in which the individual is observed after the Supplement month). In all cases, the results were similar to those in Table 4: whenever even a relatively parsimonious set of demographic controls are used, the internet search coefficient is either insignificant or negative.
} 
access is a very powerful predictor of on-line search among the unemployed, and much of the variation in home access may be driven by genuinely exogenous differences in the rate of internet diffusion across space, time and income groups; in this case controlling for access could be discarding a large amount of useful variation. Thus we present both specifications.

Column 1 of Table 4 reproduces the significant difference in Table 3, where only internet search is included as a regressor. Adding a control for home internet access in Column 2 reduces the value of the coefficient. Thus, part of the apparent effect of internet use on re-employment rates in Table 3 is in fact a re-employment differential between individuals who have internet access and those who do not. This should not be surprising since these individuals may be, as discussed, more "re-employable" on unobserved dimensions.

A similar, but stronger message emerges when additional controls for observable characteristics are added in the remaining columns of Table 4. Columns 3 and 4 add controls for labor market conditions -local and occupational unemployment rates-- and for various characteristics of the unemployment spell. The latter include how long the spell had been in progress by the Supplement month, whether the individual was "on layoff" and therefore expecting recall, what activity (school, public sector employment, private sector employment, self employment, school) preceded the unemployment spell, and the reasons for leaving any previous job ("lost job" and "temporary job", with quits as the omitted category). We also include a fixed effect for the 2000 survey to capture any changes in macroeconomic conditions between the surveys. As for columns 1 and 2, we present one specification with and one without a home internet access control. The 
apparent effect of internet search on re-employment remains positive, but is again smaller and becomes statistically insignificant in the presence of a home access control.

Effects of the "control" variables in columns 3 and 4 are generally in line with expectations. For example, although the coefficient is not quite significant at conventional levels, we see that individuals with high retrospective durations are less likely to be re-employed - a result that mirrors the common finding of declining reemployment hazards in duration studies. A high occupational unemployment rate depresses job-finding rates, and individuals who worked or went to school immediately before the onset of their current unemployment spell are much more likely to be reemployed than those who did neither. Persons whose last job was in the private sector fared better in re-employment than those whose last job was in the public sector or in self-employment, or who did not work just prior to the current unemployment spell. ${ }^{13}$

Columns 5 and 6 add controls for demographic characteristics. They show, as expected, that younger workers are re-employed more quickly, and less-educated and black workers more slowly. Single men are less likely to be re-employed than single women, but married men are more likely to be re-employed than married women, possibly reflecting greater geographical search constraints among married women (Crossley, Jones and Kuhn, 1994). The internet effect on re-employment now becomes highly insignificant in both specifications.

The last two columns of Table 4 add controls for the use of other, "traditional" job search methods. Interestingly, we detect significant positive effects on re-employment for three of these methods: direct employer contact, "sent resumes" and public

\footnotetext{
${ }^{13}$ Note that in a substantial number of cases the individual's last job preceded a spell of nonparticipation, so that these "sector" indicators do not simply subdivide the group who entered unemployment directly from a job.
} 
employment agencies, which incidentally are also the search methods most commonly used by unemployed persons in our data. For the remaining methods, no statisticallysignificant effects on the job-finding rate are found. Likewise, adding the internet to one's job search strategy appears not to increase re-employment rates. In sum, when we control for observed characteristics of unemployed workers and their unemployment spells, internet job search does not appear to be effective in reducing unemployment durations.

\section{Econometric Issues}

While the results in columns 7 and 8 of Table 4 certainly suggest that incorporating the internet into one's job search strategy is ineffective in reducing jobless durations, there are at least three reasons why this conclusion may be premature. In this section we describe these reasons, and outline our strategy for dealing with them in the remainder of the paper.

A first reason why the re-employment probits summarized in Table 4 might fail to reveal a true, beneficial effect of internet job search is simply an inefficiency in the estimation procedure. In particular, any probit focusing on a worker's labor force status at only a single date (in the above case 12 months after his/her search activity is observed) discards a considerable amount of information on the actual duration of unemployment. To address this issue, in what follows we shall estimate duration models that incorporate all the available information about a worker's jobless spell following the Supplement date. Of course, the information available to us on durations in the CPS is highly discrete: at best, we only know the month in which re-employment occurred; in some cases (the gap between the two four-month CPS observation "windows"), we only know that re-employment occurred during an eight-month period. This makes 
continuous-time duration models highly inappropriate. For this reason we develop and estimate a discrete-time hazard model that takes into account the particular features (potentially large failure "windows" whose structure varies across observations) of CPS duration data, while still allowing for a fully flexible form of the baseline hazard function.

A second reason why the estimates in Table 4 might disguise a true, beneficial effect of internet search on jobless durations results from the fact that our data is sampled at random from the stock of workers who were unemployed in the month of the Computer and Internet supplement. As a result, the probability of being in this sample is directly proportional to the dependent variable -i.e. the length of an individual's completed unemployment spell-- a property sometimes referred to as length-biased sampling. Since, in the simplest case, such a systematic undersampling of short spells will bias our internet search coefficients towards zero ${ }^{105}$, addressing this issue is also essential to ruling out a true, beneficial effect of internet search on jobless durations. In what follows, we will augment our duration model using a technique introduced by Lancaster (1979) to address this issue. Essentially we will condition each observation's contribution to the likelihood function on the fact that it lasted long enough to be observed in our sample.

The remaining potential source of bias in Table 4 concerns the endogeneity of the internet job search variable. For example, one might be concerned that individuals who look for work on line are a positively-selected sample, in the sense that they are more

\footnotetext{
${ }^{14}$ Existing discrete-time hazard models, such as Meyer's (1990) require the structure of intervals to be the same across observations.

${ }^{15}$ Suppose that (aside from a constant term) internet search was the only regressor in a simple OLS regression model, and that its true effect was to reduce unemployment durations. Then the systematic undersampling of short durations induced by stock sampling will induce a positive correlation between the
} 
motivated and able to find a new job than observationally equivalent non-internet searchers. Indeed as already noted, this claim is sometimes made by internet job sites in marketing their services to employers. Of course, if this is the case, then the estimates in Table 4 exaggerate the benefits of internet job search, thus strengthening the case that internet job search does not reduce unemployment durations.

But what of the possibility of negative selection into internet search on unobservables? We can think of at least three mechanisms that could generate this. First, as suggested by Holzer (1987) in another context, persons who use formal and anonymous job search channels such as the internet may be doing so because their informal contacts and social networks are poor. ${ }^{16}$ Second, and related, is the possibility of private information about re-employability: persons using a larger number of search methods -including the internet - may do so in response to private information that their search prospects are particularly poor. Finally, especially conditioning on home internet access, internet job search is a very low-cost job search method. Thus the costs of engaging in it are unlikely to screen out individuals with only a very marginal interest in finding a new job. Given these possibilities, in order to complete the case against an unemployment-reducing effect of internet search we would need to rule out negative selection as an explanation of the positive partial correlation between internet search and jobless durations we observe in our data.

In order to address the endogeneity issue, we need to do two things: one is to identify some instrumental variables that affect internet use but are unlikely to be correlated with idiosyncratic variation in individual workers' "re-employability". The 
second is to develop a means of incorporating these instruments (which are essentially exclusion restrictions) into a duration model that both handles the peculiarities of CPS duration data and accounts for the length-biased sampling problem discussed above. Regarding the latter issue, we shall proceed by jointly modelling the process of selection into internet job search among the unemployed and the duration of search. By adapting a technique first used by Han and Hausman (1990) in another context, we are able to allow the idiosyncratic, unobserved determinants of both these outcomes to be correlated, and to estimate the degree of correlation empirically.

Regarding instruments, we propose two sets. The first is a set of indicators of internet use by other members of the respondent's household outside the home. The rationale is that the presence of such a person in the household should reduce any costs of becoming familiar with the internet or with on-line job search sites. Further, unlike the total variation in internet job search, internet search that is induced by the above factors should not be affected by unobserved adverse information about the individual's jobfinding prospects. Also, internet use associated with having close contact with internetusers is unlikely to be a response to poor informal networks.

Our alternative set of instruments comprises three variables measuring mean internet access costs and internet diffusion at the state level. These are the mean level of access fees paid by internet users in the respondent's state, the share of households in the respondent's state who need to make a long-distance telephone call to access the internet, and simply the state mean home internet access rate. Because these are state means, they should be purged of any individual idiosyncracies in re-employability. Also, since (at

\footnotetext{
${ }^{16}$ In particular, Holzer suggests that minority youth disproportionately use formal and anonymous job search networks in part due to low access to informal contacts in the world of work, and that their reliance on formal methods in part explains their lower job-finding rates.
} 
least in two of the three cases) they focus on the costs rather than benefits of internet job search, they should not be contaminated by unobserved private information regarding expected unemployment durations, either across individuals or states.

It is probably worth noting that, while a good case can be made that these instruments purge our estimates of any spurious negative correlation between internet search and re-employment, they may go too far in that direction. For example, one might argue that, despite our controls for state unemployment rates, our state-level internet access means are correlated with unobserved labor demand shocks that reduce unemployment durations. Or one might argue that, controlling for observables, highlyreemployable unemployed persons disproportionately live in households with persons who use the internet at non-home locations. If anything, therefore, our instruments are probably biased towards estimating an unemployment-reducing internet search effect; thus if we fail to find a statistically significant beneficial effect even with these instruments, we can be quite sure that internet search is ineffective in shortening unemployment spells.

The analysis in the remainder of the paper proceeds as follows. Section 5 develops and estimates a duration model that uses all the available information on durations and takes account of the peculiar structure of CPS duration data. Section 6 then develops an extension of this model that incorporates both length-biased sampling and endogenous selection into internet search. Section 7 discusses the results of estimating this model, which addresses all three of the above econometric concerns simultaneously.

\footnotetext{
${ }^{17}$ Han and Hausman (1990) use a bivariate normal distribution in combination with a flexible baseline hazard to model potentially correlated competing risks.
} 


\section{A Univariate Duration Model}

We begin, as is common, by assuming the hazard rate into re-employment, $\lambda(\tau)$, is separable into a baseline component that depends on elapsed duration $\lambda_{0}(\tau)$, and a component that depends on a linear combination of observed characteristics $X_{i}$ and estimated parameters $\beta$ :

$$
\lambda(\tau)=\lambda_{0}(\tau) \cdot \exp \left(-X_{i} \beta\right)
$$

From assumption (1) it follows that (see Kiefer 1988, pp. 664-665):

$$
\log \Lambda_{0}\left(t_{i}\right)=X_{i} \beta+\mu_{i}
$$

where the random variable $\Lambda_{0}\left(t_{i}\right)$ is the integrated baseline hazard up to each observation's realized duration, i.e.:

$$
\Lambda_{0}\left(t_{i}\right)=\int_{0}^{t_{i}} \lambda_{0}(\tau) d \tau
$$

and where $\mu_{i}$ follows a type- 1 extreme-value distribution. ${ }^{18}$ Thus the transformed duration variable, $\log \Lambda_{0}\left(t_{i}\right)$,--which is monotonically increasing in $t_{i^{-}}$can be thought of as the dependent variable in a linear regression.

Suppose now that a particular unemployment spell is known to have ended between two dates, $t_{a}<t_{b}$. Defining $\delta_{a} \equiv \log \Lambda_{0}\left(t_{a}\right)$ and $\delta_{b} \equiv \log \Lambda_{0}\left(t_{b}\right)$, the likelihood of such a spell is just:

$$
F\left(\delta_{a}-X_{i} \beta\right)-F\left(\delta_{b}-X_{i} \beta\right),
$$

where $\mathrm{F}(\cdot)$ is the cdf of $\mu_{i}$. Durations known only to have ended after, say, $t_{a}$ (i.e. rightcensored durations) have a likelihood of $1-F\left(\delta_{a}-X_{i} \beta\right)$; durations known to have ended between $t=0$ and, say, $t_{b}$, have a likelihood of $F\left(\delta_{b}-X_{i} \beta\right)$. 
In our data, job searchers are observed no more frequently than once per month. Recognizing this discreteness, we divide the set of possible jobless durations into disjoint intervals. Denote the number of such intervals by $\mathrm{T}+1$; in the results reported in Table 5 (which focus on post-Supplement durations only), we used eight intervals: 0-1, 1-2, 23, 3-10, 10-11, 11-12, 12-13 and more than 13 months. For some of our observations (for example those persons observed as unemployed in one month and employed the next), we know in exactly which of these intervals their unemployment spell ended. Others are right-censored, due to attrition or rotation out of the sample. For yet others (including, but not limited to, persons who were not matched in a period before they are first observed in employment) we know only that they became employed at some point within a set of adjacent intervals.

To allow for the latter types of observations, define $V_{i}$ as a 1xT vector of "lower bound" dummy variables (think of these as applying, in order, to each of the $\mathrm{T}+1$ intervals defined above except the highest one). Set $\underline{V_{i}}$ equal to zero for all intervals except the one preceding the interval in which worker $i$ 's unemployment spell is known to have ended. ${ }^{2}$ Define $\bar{V}_{i}$ as a 1xT vector of upper bound dummy variables, equal to zero for all intervals except the one during which we knew the unemployment spell ended. ${ }_{22}^{2}$ Finally, let $\delta$ be a Tx 1 coefficient vector corresponding to the "cut points" between the above intervals. Because the elements of $\delta$ correspond to the log of the

\footnotetext{
${ }^{18}$ The cdf for the extreme-value distribution is given by $F\left(\mu_{i}\right)=\exp \left(-\exp \left(-\mu_{i}\right)\right)$

${ }^{19}$ Unlike observed durations which must be positive, note that the transformed durations and the error term $\mu_{i}$ occupy the entire real line.

${ }^{20}$ Appendix B describes how we constructed unemployment durations from the matched CPS files.

${ }^{21}$ If the observation is right-censored this is the interval before it became right-censored; if the observation became re-employed during the first interval $\underline{V_{i}}$ is a vector of zeroes.

${ }^{22}$ If the observation is right-censored, $\bar{V}_{i}$ is a vector of zeroes.
} 
integrated baseline hazard at the upper end of each interval, and because $\delta$ is estimated, this procedure allows for an unrestricted baseline hazard function.

Putting all the above together, the log likelihood for the entire sample can be expressed as:

$$
\begin{aligned}
\log L= & \sum_{\text {Cens }=L} \log \left[F\left(\bar{V}_{i} \delta-X_{i} \beta\right)\right]+ \\
& \sum_{\text {Cens }=0} \log \left[F\left(\bar{V}_{i} \delta-X_{i} \beta\right)-F\left(\underline{V_{i}} \delta-X_{i} \beta\right)\right]+ \\
& \sum_{C \text { Cens }=R} \log \left[1-F\left(\underline{V_{i}} \delta-X_{i} \beta\right)\right] .
\end{aligned}
$$

where Cens $=\mathrm{L}, 0$ and $\mathrm{R}$ indicates the observation is left-censored, not censored, or rightcensored, respectively. (Note that we refer to observations that became re-employed in the first month of their unemployment spell as left-censored because the transformed duration variable, $\log \Lambda_{0}\left(t_{i}\right)$, has no lower bound for this group).

While the derivation leading to (5) relies on $F$ having an extreme value distribution, in Table 5 we present estimation results based on a normal distribution for $F$ as well. This ordered probit-type specification does not follow directly from the proportional-hazards specification in (1), but yields predicted durations (both with and without internet search) that are very similar to those obtained from the extreme-value specification. 2.3 The value of the ordered-probit specification is that it allows us to model correlation between the disturbance term $\left(\mu_{i}\right)$ in our unemployment duration equation (2), and unobserved characteristics that induce unemployed individuals to look for work on line in the following section.

\footnotetext{
${ }^{23}$ Predicted survivor curves for all four specifications in Table 5 are available from the authors. The normal and extreme-value based curves are essentially indistinguishable from each other. The likely reason why functional form is of so little consequence is that our specification allows for an unrestricted baseline hazard: moving the "cut points" for the two distibutions gives us a large number of degrees of freedom with which to fit observed transition patterns.
} 
As in Table 4, Table 5 presents specifications with and without controls for home internet access. (Note that because the index $X_{i} \beta$ enters equation (1) negatively, a positive coefficient in Table 5 indicates that the variable in question reduces the hazard rate, i.e. it increases expected unemployment duration). Recalling also that our estimation framework so far continues to treat pre-Supplement unemployment duration as an exogenous covariate, Table 5 shows that persons who are far into their unemployment spells (i.e. with high retrospective durations in the Supplement month) have longer remaining unemployment durations after that date. Durations were lower in the 2000 Supplement, reflecting the tighter aggregate labor market conditions prevailing around the time of that survey. High state unemployment rates raise unemployment durations. As in Table 4, younger workers have shorter unemployment durations and older workers remain unemployed longer. One interesting difference from Table 4 is that persons with home internet access now have significantly shorter jobless durations. The most surprising finding from Table 5, however, is that according to the coefficient estimates, internet job search now appears to be not simply ineffective, but in fact significantly counterproductive. In other words, holding constant observable characteristics of the person and the previous duration of the unemployment spell, persons who searched for work on line actually entered re-employment more slowly than those who did not, during the period after we observe whether they search on line. While not proving that internet search is in fact counterproductive, these results certainly present a strong preliminary case against the argument that internet job search reduces unemployment durations. Of course, these results are also consistent with negative selection into internet search on unobservables, especially in the specification where internet access is held constant, where the estimated counterproductive effect is the strongest. 


\section{Length-Biased Sampling and Endogeneity of Internet Search: Methods}

a) Length-Biased Sampling

We begin again with the linear-regression representation of the proportional hazard model in (2), but now re-interpret the duration variable $t_{i}$, as total spell duration including the retrospective component, $t_{i}^{R}$. Consider again a spell observed in our data (thus it is known to have lasted at least $t^{R}$ months), known to have ended between two dates, $t_{a}<t_{b}$ (where both $t_{a}$ and $t_{b}$ must exceed $t^{R}$ ). Thus the information provided by our data is that, conditional on lasting at least $t^{R}$ months, this spell lasted between $t_{a}$ and $t_{b}$ months. Once again defining $\delta_{a} \equiv \log \Lambda_{0}\left(t_{a}\right)$ and $\delta_{b} \equiv \log \Lambda_{0}\left(t_{b}\right)$, and now $\delta^{R} \equiv \log \Lambda_{0}\left(t^{R}\right)$, the likelihood of such a spell is 24 .

$$
\frac{F\left(\delta_{a}-X_{i} \beta\right)-F\left(\delta_{b}-X_{i} \beta\right)}{1-F\left(\delta^{R}-X_{i} \beta\right)} .
$$

Next, we divide up the set of possible total durations (including the retrospective portion) into $\mathrm{T}+1$ intervals and define the $1 \mathrm{xT}$ lower- and upper- bound vectors $V_{i}$ and $\bar{V}_{i}$ as before for these spell durations. ${ }^{-}$Lastly, define the $1 \mathrm{xT}$ vector $V_{i}^{R}$ as equal to zero for all intervals except the one preceding the supplement month. (Thus, for example, with month-long intervals, a worker who became unemployed in September 1998 has the third --November 1998-- element of $V_{i}^{R}$ set to one and the rest to zero).

Parallel to (6), the log likelihood for the entire sample, corrected for length-biased sampling, can now be written:

\footnotetext{
24 This assumes a constant inflow rate into unemployment before the Supplement month.

${ }^{25}$ In the results reported here we used 22 intervals for these total durations. With the exception of months 7 and 8 (which were combined due to small sample sizes) these comprised individual months up to 16.

Beyond that, the categories were 16-22, 23-26, 27, 28, 29-37, and over 38 months.
} 


$$
\begin{aligned}
\log L= & \sum_{\text {Cens }=L} \log \left[F\left(\bar{V}_{i} \delta-X_{i} \beta\right)\right]+ \\
& \sum_{\text {Cens }=0} \log \left[\frac{F\left(\bar{V}_{i} \delta-X_{i} \beta\right)-F\left(\underline{V_{i}} \delta-X_{i} \beta\right)}{1-F\left(V_{i}^{R} \delta-X_{i} \beta\right)}\right]+ \\
& \sum_{\text {Cens }=R} \log \left[\frac{1-F\left(V_{i} \delta-X_{i} \beta\right)}{1-F\left(V_{i}^{R} \delta-X_{i} \beta\right)}\right] .
\end{aligned}
$$

Note that because all "left-censored" spells in this context are new spells, no lengthbiased sampling correction applies to them.

Of course, parameter estimates in (7) have a different interpretation than in (5): they refer to the effect of each covariate on total unemployment durations (including the retrospective portion) rather than on post-Supplement durations. In the interpretation of both (5) and (7), note again that -given the absence of internet search data at any dates other than the Supplement month — we treat and interpret internet search, like all our other covariates, as a non-time-varying characteristic of the unemployment spell. ${ }^{6}$ b) Endogeneity

Finally, to incorporate the possible endogeneity of internet job search into our model, we rewrite (2) as:

$$
\log \Lambda_{0}\left(t_{i}\right)=X_{i} \beta+y_{i} \gamma+\mu_{i}
$$

where $y_{i}$ (previously included in $X_{i}$ ) is the internet search dummy, with coefficient $\gamma$.

Now define the difference between the marginal benefit and marginal cost of internet job search as the latent variable:

$$
y_{i}^{*}=W_{i} \theta+\varepsilon_{i} .
$$

\footnotetext{
${ }^{26}$ Any other treatment of internet search would require data on internet search activity at more than one point during an unemployment spell, which is currently not available.
} 
where $W_{i}$ is a vector of exogenous, non-time varying covariates, $X_{i}$, plus a set of instrumental variables excluded from $X_{i}$. The latent variable $y_{i}^{*}$ is not observed, but instead we observe:

$$
y_{i}=\left\{\begin{array}{ll}
1 & \text { if } y_{i}^{*}>0 \\
0 & \text { otherwise }
\end{array} .\right.
$$

Our concern is that $\varepsilon_{i}$ in (9) may be correlated with $\mu_{i}$ in (8). This leads to bias, e.g., in the estimate of $\gamma$ in (8) because the endogenous variable, $y_{\mathrm{i}}$, is correlated with the error term $\mu_{i}$.

Unfortunately, we are aware of no widely-accepted technique for estimating hazard models with an endogenous covariate. The difficulty, essentially, is modeling the joint distribution of $\varepsilon_{i}$ and $\mu_{i}$ when $\mu_{i}$ is non-normal. Our approach is therefore to extend the "ordered-probit" version of (7) to the bivariate case, where standard bivariate normal results can be used to model the joint distribution of $\varepsilon_{i}$ and $\mu_{i}$. With the exception of the interval nature of our duration measure and the correction for length-biased sampling, our approach is similar to Greene's (1998) bivariate probit model with an endogenous dummy variable.

To extend the model in (7) to the case where $\varepsilon_{i}$ and $\mu_{i}$ have a joint normal distribution with (potentially) non-zero correlation, note first that an observation will be in our sample iff:

$$
t_{i}>t^{R}
$$

or, $\quad \log \Lambda_{0}\left(t_{i}\right)>\delta^{R}$

or, $\quad \mu_{i}>\delta^{R}-X_{i} \beta-y_{i} \gamma$ 
or, $\quad \mu_{i}>\delta^{R}-X_{i} \beta-I\left(W_{i} \theta+\varepsilon_{i}\right) \gamma$

where the indicator function, $I\left(\right.$ ), returns 1 if $y_{i}^{*}>0$ and 0 otherwise. Thus (for the bivariate normal case) the likelihood of being in the sample is given by:

$$
\Phi_{2}\left(z_{0},-z_{11}, \rho\right)+\Phi_{2}\left(-z_{0},-z_{10},-\rho\right)
$$

where $\Phi_{2}$ is the standard bivariate normal cdf with correlation $\rho$, and:

$$
\begin{aligned}
& z_{0}=W_{i} \theta \\
& z_{11}=V_{i}^{R} \delta-X_{i} \beta-\gamma \\
& z_{10}=V_{i}^{R} \delta-X_{i} \beta .
\end{aligned}
$$

By adjusting the denominator in (7) to reflect this new condition, and the numerator in (7) to account for the joint distribution of $\mu_{i}$ and $\varepsilon_{i}$, we can obtain an unbiased estimate of $\gamma$. To express the bivariate likelihood function, first define:

$$
q=2 y-1
$$

(thus $q=1$ when $y=1$, and $q=-1$ when $y=0$ ),

The complete likelihood function for this model can then be written:

$$
\begin{aligned}
& L=\sum_{\text {Cens }_{i=L}} \log \left[\Phi_{2}\left(q z_{0}, z_{3},-q \rho\right)\right] \\
& \sum_{\text {Cens }_{i}=0} \log \left[\frac{\Phi_{2}\left(q z_{0}, z_{3},-q \rho\right)-\Phi_{2}\left(q z_{0}, z_{2},-q \rho\right)}{\Phi_{2}\left(z_{0},-z_{11}, \rho\right)+\Phi_{2}\left(-z_{0},-z_{10},-\rho\right)}\right]+ \\
& \sum_{\text {Cens }_{i}=R} \log \left[\frac{\Phi_{2}\left(q z_{0},-z_{2}, q \rho\right)}{\Phi_{2}\left(z_{0},-z_{11}, \rho\right)+\Phi_{2}\left(-z_{0},-z_{10},-\rho\right)}\right] .
\end{aligned}
$$

where:

$z_{2}=\underline{V}_{i} \delta-X_{i} \beta-y_{i} \gamma$, and

$z_{3}=\bar{V}_{i} \delta-X_{i} \beta-y_{i} \gamma$

${ }^{27}$ See also Greene (2000), pp. 852-856. 


\section{Endogeneity of Internet Search and Length-Biased Sampling: Results}

Results from maximizing the likelihood function in equation (12) are presented in Table 6. In all, six specifications are reported, each of which contains two equations: a "search" equation for the determinants of internet search, and an unemployment duration equation. The first two columns present estimates of the entire model, but with the correlation $(\rho)$ between the search and duration error terms $\left(\mu_{i}\right.$ and $\left.\varepsilon_{i}\right)$ constrained to equal zero. Essentially, this amounts to introducing the correction for length-biased sampling as well as the discrete-time hazard framework described in Sections 5 and 6(a), but not the correction for endogenous internet search in Section 6(b). As in previous tables, we present a version that includes controls for home internet access (in both the search and duration equations) and one that does not. To economize on space we report only the internet search and internet access coefficients in the duration equation, and the estimated correlation between the error terms, $\rho$.

The main message of columns 1 and 2 of Table 6 is that length-biased sampling alone cannot account for our estimated "counterproductive" search effects. While the internet search effect on durations is now insignificant in the absence of an internet access control (column 1), column 2 shows that this is due to two offsetting effects: (1) unemployed individuals with home internet access have shorter unemployment durations, whether they search on line or not; and (2) among the unemployed with access, those who use the internet to look for work actually have longer unemployment durations than those who do not. Whether these longer durations are a perverse causal effect of internet

\footnotetext{
${ }^{28}$ Complete results for the four specifications with $\rho$ unrestricted are provided in Appendix C; results for the two remaining specifications are very similar. Note also that when $\rho=0$, the instruments used in the search equation should not, and do not affect our estimates of the duration equation. Thus Table 6 does not present separate estimates for the two instrument sets when $\rho=0$.
} 
search or an artifact of selection on the remaining unobservables cannot be determined from columns 1 and 2; to address that question we must turn to the estimates in the remainder of the Table.

As noted, columns 3 through 6 of Table 6 relax the $\rho=0$ constraint. Columns 3 and 4 present estimates of the duration equation when instrument set 1 -non-home internet use by other household members - is used; columns 5 and 6 use state means of internet access costs and internet diffusion as instruments. Three features are noteworthy: first, all the positive estimated effects of internet search on durations disappear; thus internet job search no longer appears to be counterproductive. Instead (point two), the model prefers to attribute the positive partial correlation between internet search and unemployment durations to what we have been calling negative selection: all our estimates of $\rho$ are positive, indicating that unemployed individuals who have a higher unexplained disposition to look for work on line tend to have longer unemployment durations. Third, however, neither the estimate of $\rho$ nor the estimated effect of internet search on unemployment durations is significantly different from zero. Thus, despite fairly powerful instruments (including some $t$-ratios as high as 5 - see Appendix C), our model is unable to distinguish selection on unobservables from a causal effect of internet search.

Can our data, then, when all potential biases are taken into account, place any restrictions on either the selection process into internet search or on its causal effects? A reasonable lower-bound estimate of the causal effect of internet search is zero: it is hard to imagine anyone adding this element to his/her search strategy if it makes him or her worse off. Imposing a causal internet effect of zero on the models estimated in Table 6 yields estimates for $\rho$ of $.107(.033)$ and $.106(.033)$ respectively for the household access 
and the state mean instruments respectively; these are of course very significantly different from zero. ${ }^{29}$ Imposing any beneficial internet search effect yields even larger estimates of $\rho$. We thus conclude that internet job searchers must be negatively selected on unobservables. Further, if one is to reconcile our data with a true, unemploymentreducing effect of internet search, this negative selection must be even stronger than the baseline levels identified above.

\section{Summary and Discussion}

This article has examined the factors affecting unemployed U.S. workers' choice to use internet methods to search for jobs, and has attempted to isolate the causal effect of adopting internet job search methods on these workers' job-finding rates. After accounting for both observable and unobservable differences between internet searchers and other unemployed workers, for the large gaps in measured unemployment durations induced by the CPS rotation structure, and for the length-biased sampling problem inherent in data collected from the stock of unemployed workers at a point in time, our estimates show the following. First, unemployed internet searchers are positively selected on observables: i.e. compared to other unemployed workers, they have measured characteristics such as education and occupations which are associated with faster reemployment whether or not the internet is used for job search. Second, internet searchers appear to be negatively selected on unobservables, i.e. they have unobservable characteristics such as low motivation or poor informal networks, that are associated with longer unemployment spells. Finally, we are unable to detect any statistically significant beneficial causal effect of internet job search on re-employment rates, and note that if

\footnotetext{
${ }^{29}$ Standard errors in parentheses. These estimates are for the case where internet access controls are
} 
such an effect is to be consistent with our data, negative selection on unobservables would have to be especially strong.

Is our finding that internet jobseekers are negatively selected on hard-to-observe characteristics a plausible one, given claims to the contrary by most on-line job search sites? While this was not our prior when we started this research, we have suggested three mechanisms - poor informal networks, adverse private information about re-employment prospects, and low user costs - that might give rise to negative selection. Further evidence that such processes might be important is available from other sources. For example, evidence of poor informal contacts emerged when one of us described our early results from this project to a newspaper reporter. The reporter, who teaches minority college students at night, remarked that a large majority of her students looked for work on line, and attributed this to the fact that very few of them had informal contacts in the world of white-collar work. ${ }^{30}$ Evidence suggesting that adverse private information about re-employment prospects raises search intensity in general is available from the CPS itself: In a previous version of this paper (available from the authors) we present counts of the number of "traditional" search methods used during the course of workers' unemployment spells. Workers with (ex post) long unemployment durations use a larger number of methods throughout their unemployment spell, suggesting that they anticipate long spells and attempt to compensate for this by searching harder early in the spell.

Finally, anecdotal evidence of negative self-selection is available directly from the recruiting industry itself. In a personal interview, a professional recruiter informed us that he avoids internet job boards altogether because of a concern about negative

included in both equations of the model.

${ }^{30}$ Of course, for poorer networks to explain our result, they must not already be captured by our "contacted friends and relatives" variable. This is quite possible: informal networks often yield job leads without any 
selection. This is echoed by a recruiting executive quoted in Autor (2001), who observed that internet job boards are populated with four types of resumes: "the unhappy (and thus probably not a desirable employee); the curious (and therefore likely to be a 'job-hopper'; the unpromotable (probably for a reason); and the unemployed (probably for a worse reason)". It is also echoed in the development of tools such as "resume spiders" and "resume robots" in the recruiting industry, whose main aim is to circumvent job boards by trolling the internet for "passive" job seekers who have not decided to look for work on line.

While we have made considerable progress in understanding the internet search process in the U.S. economy, further research is clearly needed to conclusively disentangle selection on unobservables and causation in this context, as it is in so many others. Such work, in our view, should ideally have an experimental component, and -because at least some internet component is now entering most workers' job search strategies-- will need to carefully distinguish the different ways in which the internet is used: visiting job boards, posting resumes thereon, visiting company web sites, and simply emailing friends and relatives, among other methods. From our current work, however, two results are quite clear. First, the process of selection into internet search is apparently quite different from the notion that this is an "elite" job search method used disproportionately by highly-motivated and highly-re-employable workers. Second, given our evidence, claims by internet search firms that using their services will reduce workers' search times are inconsistent with other claims made by those same firms that their resumes are positively selected on hard-to-document characteristics.

worker initiatives (Granovetter 1995); Skuterud (2001) finds that a large fraction of new job starts are not preceded by any worker search at all 


\section{Appendix}

\section{A. Construction of Matched CPS Sample}

To capture as much information as possible, each of post-Supplement file was matched separately with its corresponding Supplement file. Below we describe the four steps involved in matching the December 1998 Supplement with the ten subsequent CPS files that contain common survey respondents. The procedure for the August 2000 file was identical.

1. Construct the master data set by extracting the 3 merging variables: (i) the household identifier (HRHHID), (ii) the individual line number with in the household (PULINENO) and (iii) the household number (HUHHNUM), the labor force status variable (PEMLR) and a set of non-time varying covariates for each observation from the raw December 1998 CPS file. Also, create the set of instrumental variables by using HRHHID, PULINENO, spouse line number (PESPOUSE) and parent line number (PEPARENT) to reshape the data set and identify relationships within households. The resulting master data set contains 122,935 observations.

2. Create the 10 matching data sets by extracting the 3 merging variables, in addition to the labor force status, sex (PESEX), age (PRTAGE), race (PERACE) and person type (PRPERTYP) variables from the January 1999, February 1999, March 1999, September 1999, October 1999, November 1999, December 1999, January 2000, February 2000 and March 2000 raw CPS files. For each using data set use the month-in-sample variable (HRMIS) to limit the sample to those observations that potentially appear in the December 1998 file. The resulting "matching" data sets contain the following sample sizes:

$\begin{array}{ll}\text { January } 1999 & 93,129 \\ \text { February 1999 } & 61,979 \\ \text { March 1999 } & 30,917 \\ \text { September 1999 } & 14,961 \\ \text { October 1999 } & 30,541 \\ \text { November 1999 } & 46,538 \\ \text { December 1999 } & 61,831 \\ \text { January 2000 } & 47,208 \\ \text { February 2000 } & 31,569 \\ \text { March 2000 } & 15,710\end{array}$

3. Merge the master data set with each of the 10 matching data sets using the 3 merging variables discarding all observations that appear only in the matching data set. This produces 10 files each containing 122,935 observations. Then merge these 10 files producing a single merged data set containing 122,935 observations.

4. Following the algorithm proposed by Madrian and Lefgren (1999), identify matches in the merged data set for which any of the following are true: (i) a month-to-month change in sex; (ii) a monthto-month change in race; (iii) the difference in age from month-to-month is less than -1 or greater than 3; or (iv) the individual went from being classified as an adult civilian to a child or as an adult, armed forces member to a child. In particular, we identify the survey month in which the implausible match was made. In creating our duration data we discard observations where an implausible transition occurs before an observation makes a transition to employment or out of the labor force (see Section B for the frequencies of these discards).

The percent of potential matches made from merging the master and matching data sets are tabulated below: 


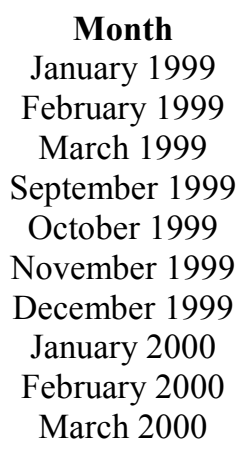

Match Rate (\%)
91.7
87.6
83.2
68.1
67.1
66.3
64.9
64.3
62.9
61.2

Only 10.4 percent of observations were not matched at least once after the Supplement date. The match rate for internet searchers and others were very similar. For example, in January 1999 the match rate for internet searchers is 93.6 compared to 91.5 for those not reporting internet search in the previous month. In order to more directly assess the possibility that our results might be driven by internet searchers who were not matched because they moved to take jobs, we replicated our entire analysis treating all individuals whose spells were censored due to a failure to match as becoming re-employed in the month following the censoring. There was very little change.

\section{B. Construction of Duration Data}

The data set containing the unemployment duration information was constructed in the following seven steps (again the description focuses for concreteness on the December 1998 supplement; procedures for August 2000 were identical).

1. Extract the sample of observations from the merged data set described in Section A that were unemployed and actively searching in December 1998. The resulting data set contains 2,027 observations.

2. Create variables ETRANSIT and NTRANSIT which indicate the months that the first employment or out of the labor force transition respectively was observed. Observations with missing values for both of these variables were never observed making a transition from the unemployed state. For these observations create the variable LASTU indicating the last month in which the observation was observed in the unemployed state. These 3 variables are tabulated below:

$\begin{array}{cccc}\text { Month } & \text { ETRANSIT } & \text { NTRANSIT } & \\ \text { December 1998 } & - & - & \text { LASTU } \\ \text { January 1999 } & 325 & 403 & 434 \\ \text { February 1999 } & 97 & 78 & 87 \\ \text { March 1999 } & 31 & 17 & 36 \\ \text { September 1999 } & 95 & 54 & 3 \\ \text { October 1999 } & 61 & 23 & 0 \\ \text { November 1999 } & 37 & 20 & 2 \\ \text { December 1999 } & 29 & 13 & 4 \\ \text { January 2000 } & 4 & 6 & 6 \\ \text { February 2000 } & 2 & 1 & 0 \\ \text { March 2000 } & 0 & 0 & 3 \\ \text { TOTAL } & 681 & 615 & 731\end{array}$

3. Construct the variable t1, which is the retrospective unemployment spell reported in December 1998. In the raw data this variable is reported in weeks so the following transformation is made:

$$
\mathrm{t} 1 \text { = RAW VARIABLE / } 4 .
$$


4. Construct the variable 2 , which gives the lower bound of the post-December 1998 unemployment spell. For all the observations it is calculated by determining how many months after December 1998 the observation was last seen unemployed. This number is added to 0.25 , to allow us to take logarithms of observations that are never observed after December 1998, to produce $\mathrm{t} 2$.

5. Construct the variable t3, which gives the upper bound of the post-December 1998 unemployment spell. Since all the NTRANSIT and LASTU observations are right-censored, $\mathrm{t} 3$ only contains values for the ETRANSIT observations. It is calculated simply as the number of months after December 1998 that the employment transition is observed.

6. Construct the variables $\mathrm{t} 21$ and $\mathrm{t} 31$, which give the lower and upper bounds of the complete unemployment spells. They are calculated as:

$$
\begin{aligned}
& \mathrm{t} 21=\mathrm{t} 2+\mathrm{t} 1 \\
& \mathrm{t} 31=\mathrm{t} 3+\mathrm{t} 1
\end{aligned}
$$

7. For observations with a LASTU value of September 1999 or later the reported retrospective spell in the final month the observation is seen is used to insure that spells were continuous through the longitudinal gaps. If the retrospective spell is shorter than $\mathrm{t} 2$, the lower bound spell is adjusted by subtracting the retrospective spell plus 0.25 from $\mathrm{t} 2$. This adjustment is made to 14 observations. The same adjustment to t2 is made to observations with an NTRANSIT value of October, 1999 or later and an observed retrospective spell in the previous month. This adjustment is made to 18 observations. Finally, for observations with an ETRANSIT value of September, 1999 or later the reported retrospective spell in the previous month, if it is observed, is used to check for continuous unemployment spells. If the retrospective spell is shorter than $\mathrm{t} 2$, the lower bound spell is adjusted as above and $\mathrm{t} 3$ is changed to missing. This change was made to 14 observations. 
C: Bivariate lognormal duration models with length-biased sampling correction, full results ( $\rho$ unconstrained).

\begin{tabular}{|c|c|c|c|c|c|c|c|c|}
\hline \multirow[b]{2}{*}{ Instrument set: } & \multicolumn{4}{|c|}{ Internet search equation } & \multicolumn{4}{|c|}{ Duration equation } \\
\hline & \multicolumn{2}{|c|}{$\begin{array}{l}\text { No Access controls } \\
\text { (1) }\end{array}$} & \multicolumn{2}{|c|}{$\begin{array}{l}\text { Access controls } \\
\text { (1) }\end{array}$} & $\begin{array}{l}\text { No Acces: } \\
\text { (1) }\end{array}$ & $\begin{array}{c}\text { controls } \\
(2)\end{array}$ & \multicolumn{2}{|c|}{$\begin{array}{l}\text { Access controls } \\
\text { (1) }\end{array}$} \\
\hline Net search & & & & & $\begin{array}{l}-0.303 \\
(0.426)\end{array}$ & $\begin{array}{l}-0.147 \\
(0.696)\end{array}$ & $\begin{array}{l}-0.036 \\
(0.466)\end{array}$ & $\begin{array}{l}-0.309 \\
(0.425)\end{array}$ \\
\hline 2000 supplement & $\begin{array}{l}0.427^{\star} \\
(0.053)\end{array}$ & $\begin{array}{l}0.296^{*} \\
(0.101)\end{array}$ & $\begin{array}{l}0.170^{*} \\
(0.059)\end{array}$ & $\begin{array}{l}0.231^{*} \\
(0.107)\end{array}$ & $\begin{array}{l}-0.409^{*} \\
(0.091)\end{array}$ & $\begin{array}{l}-0.429^{*} \\
(0.110)\end{array}$ & $\begin{array}{l}-0.418^{*} \\
(0.074)\end{array}$ & $\begin{array}{l}-0.405^{*} \\
(0.075)\end{array}$ \\
\hline On layoff & $\begin{array}{l}-0.103 \\
(0.091)\end{array}$ & $\begin{array}{l}-0.097 \\
(0.090)\end{array}$ & $\begin{array}{l}-0.109 \\
(0.100)\end{array}$ & $\begin{array}{l}-0.098 \\
(0.100)\end{array}$ & $\begin{array}{l}-0.186 \\
(0.109)\end{array}$ & $\begin{array}{l}-0.181 \\
(0.111)\end{array}$ & $\begin{array}{l}-0.176 \\
(0.110)\end{array}$ & $\begin{array}{l}-0.182 \\
(0.109)\end{array}$ \\
\hline State ur & $\begin{array}{c}0.030 \\
(0.027)\end{array}$ & $\begin{array}{c}0.040 \\
(0.028)\end{array}$ & $\begin{array}{c}0.010 \\
(0.030)\end{array}$ & $\begin{array}{c}0.030 \\
(0.031)\end{array}$ & $\begin{array}{l}0.100^{\star} \\
(0.035)\end{array}$ & $\begin{array}{l}0.100^{*} \\
(0.036)\end{array}$ & $\begin{array}{l}0.100^{*} \\
(0.035)\end{array}$ & $\begin{array}{l}0.100^{*} \\
(0.035)\end{array}$ \\
\hline Occupation ur & $\begin{array}{l}-0.086^{*} \\
(0.016)\end{array}$ & $\begin{array}{l}-0.086^{*} \\
(0.016)\end{array}$ & $\begin{array}{l}-0.063^{*} \\
(0.017)\end{array}$ & $\begin{array}{l}-0.060^{*} \\
(0.017)\end{array}$ & $\begin{array}{c}0.005 \\
(0.020)\end{array}$ & $\begin{array}{c}0.008 \\
(0.023)\end{array}$ & $\begin{array}{c}0.008 \\
(0.019)\end{array}$ & $\begin{array}{l}0.005 \\
(0.019)\end{array}$ \\
\hline Worked before u & $\begin{array}{l}0.169^{\star} \\
(0.083)\end{array}$ & $\begin{array}{l}0.180^{*} \\
(0.083)\end{array}$ & $\begin{array}{l}0.232^{*} \\
(0.092)\end{array}$ & $\begin{array}{l}0.232^{*} \\
(0.092)\end{array}$ & $\begin{array}{l}-0.047 \\
(0.111)\end{array}$ & $\begin{array}{l}-0.053 \\
(0.114)\end{array}$ & $\begin{array}{l}-0.059 \\
(0.112)\end{array}$ & $\begin{array}{l}-0.047 \\
(0.112)\end{array}$ \\
\hline School before u & $\begin{array}{l}0.330^{\star} \\
(0.087)\end{array}$ & $\begin{array}{l}0.347^{*} \\
(0.087)\end{array}$ & $\begin{array}{l}0.294^{\star} \\
(0.094)\end{array}$ & $\begin{array}{l}0.301^{*} \\
(0.093)\end{array}$ & $\begin{array}{c}0.168 \\
(0.122)\end{array}$ & $\begin{array}{c}0.156 \\
(0.131)\end{array}$ & $\begin{array}{c}0.154 \\
(0.119)\end{array}$ & $\begin{array}{l}0.161 \\
(0.118)\end{array}$ \\
\hline Lost job & $\begin{array}{c}0.079 \\
(0.081)\end{array}$ & $\begin{array}{c}0.070 \\
(0.080)\end{array}$ & $\begin{array}{c}0.078 \\
(0.091)\end{array}$ & $\begin{array}{c}0.085 \\
(0.091)\end{array}$ & $\begin{array}{l}0.247^{\star} \\
(0.106)\end{array}$ & $\begin{array}{l}0.245^{*} \\
(0.107)\end{array}$ & $\begin{array}{l}0.245^{\star} \\
(0.106)\end{array}$ & $\begin{array}{l}0.245^{*} \\
(0.106)\end{array}$ \\
\hline Temporary job & $\begin{array}{l}-0.053 \\
(0.098)\end{array}$ & $\begin{array}{l}-0.047 \\
(0.097)\end{array}$ & $\begin{array}{l}-0.010 \\
(0.106)\end{array}$ & $\begin{array}{l}-0.003 \\
(0.106)\end{array}$ & $\begin{array}{c}0.111 \\
(0.121)\end{array}$ & $\begin{array}{c}0.111 \\
(0.122)\end{array}$ & $\begin{array}{c}0.106 \\
(0.121)\end{array}$ & $\begin{array}{c}0.106 \\
(0.121)\end{array}$ \\
\hline Private sector & $\begin{array}{l}0.288^{*} \\
(0.114)\end{array}$ & $\begin{array}{l}0.284^{\star} \\
(0.114)\end{array}$ & $\begin{array}{l}0.248^{*} \\
(0.123)\end{array}$ & $\begin{array}{l}0.259^{*} \\
(0.124)\end{array}$ & $\begin{array}{l}-0.156 \\
(0.165)\end{array}$ & $\begin{array}{l}-0.168 \\
(0.169)\end{array}$ & $\begin{array}{l}-0.158 \\
(0.163)\end{array}$ & $\begin{array}{l}-0.147 \\
(0.163)\end{array}$ \\
\hline Public sector & $\begin{array}{l}0.333^{*} \\
(0.139)\end{array}$ & $\begin{array}{l}0.320^{*} \\
(0.139)\end{array}$ & $(0.150)$ & $\begin{array}{l}0.307^{*} \\
(0.150)\end{array}$ & $\begin{array}{l}-0.316 \\
(0.204)\end{array}$ & $\begin{array}{l}-0.330 \\
(0.208)\end{array}$ & $\begin{array}{l}-0.324 \\
(0.204)\end{array}$ & $\begin{array}{l}-0.312 \\
(0.203)\end{array}$ \\
\hline Self-employed & $\begin{array}{l}0.392^{*} \\
(0.167)\end{array}$ & $\begin{array}{l}0.370^{*} \\
(0.169)\end{array}$ & $\begin{array}{l}0.410^{*} \\
(0.181)\end{array}$ & $\begin{array}{l}0.406^{*} \\
(0.183)\end{array}$ & $\begin{array}{l}-0.561^{*} \\
(0.248)\end{array}$ & $\begin{array}{l}-0.580^{*} \\
(0.252)\end{array}$ & $\begin{array}{l}-0.548^{*} \\
(0.247)\end{array}$ & $\begin{array}{l}-0.520^{*} \\
(0.247)\end{array}$ \\
\hline Age 16-25 & $\begin{array}{l}0.494^{*} \\
(0.125)\end{array}$ & $\begin{array}{l}0.582^{*} \\
(0.123)\end{array}$ & $\begin{array}{l}0.411^{*} \\
(0.137)\end{array}$ & $\begin{array}{l}0.463^{*} \\
(0.136)\end{array}$ & $\begin{array}{l}-0.197 \\
(0.176)\end{array}$ & $\begin{array}{l}-0.222 \\
(0.190)\end{array}$ & $\begin{array}{l}-0.222 \\
(0.169)\end{array}$ & $\begin{array}{l}-0.197 \\
(0.167)\end{array}$ \\
\hline Age 26-35 & $\begin{array}{l}0.432^{*} \\
(0.118)\end{array}$ & $\begin{array}{l}0.456^{*} \\
(0.118)\end{array}$ & $\begin{array}{l}0.431^{*} \\
(0.130)\end{array}$ & $\begin{array}{l}0.448^{*} \\
(0.131)\end{array}$ & $\begin{array}{l}-0.181 \\
(0.168)\end{array}$ & $\begin{array}{l}-0.200 \\
(0.180)\end{array}$ & $\begin{array}{l}-0.210 \\
(0.167)\end{array}$ & $\begin{array}{l}-0.180 \\
(0.166)\end{array}$ \\
\hline Age $36-45$ & $\begin{array}{l}0.291^{*} \\
(0.118)\end{array}$ & $\begin{array}{l}0.323^{*} \\
(0.116)\end{array}$ & $\begin{array}{l}0.252^{*} \\
(0.129)\end{array}$ & $\begin{array}{l}0.290^{*} \\
(0.130)\end{array}$ & $\begin{array}{l}-0.097 \\
(0.164)\end{array}$ & $\begin{array}{l}-0.110 \\
(0.170)\end{array}$ & $\begin{array}{l}-0.117 \\
(0.164)\end{array}$ & $\begin{array}{l}-0.098 \\
(0.162)\end{array}$ \\
\hline Age 46-55 & $\begin{array}{l}0.365^{*} \\
(0.122)\end{array}$ & $\begin{array}{l}0.373^{*} \\
(0.120)\end{array}$ & $\begin{array}{l}0.345^{\star} \\
(0.133)\end{array}$ & $\begin{array}{l}0.356^{*} \\
(0.134)\end{array}$ & $\begin{array}{c}0.194 \\
(0.169)\end{array}$ & $\begin{array}{c}0.181 \\
(0.176)\end{array}$ & $\begin{array}{c}0.176 \\
(0.170)\end{array}$ & $\begin{array}{c}0.195 \\
(0.168)\end{array}$ \\
\hline Male & $\begin{array}{l}-0.054 \\
(0.065)\end{array}$ & $\begin{array}{l}-0.047 \\
(0.064)\end{array}$ & $\begin{array}{l}-0.177^{*} \\
(0.070)\end{array}$ & $\begin{array}{l}-0.170^{*} \\
(0.070)\end{array}$ & $\begin{array}{c}0.018 \\
(0.083)\end{array}$ & $\begin{array}{c}0.019 \\
(0.084)\end{array}$ & $\begin{array}{c}0.026 \\
(0.084)\end{array}$ & $\begin{array}{c}0.023 \\
(0.084)\end{array}$ \\
\hline Married & $\begin{array}{c}0.166 \\
(0.107)\end{array}$ & $\begin{array}{l}0.155 \\
(0.105)\end{array}$ & $\begin{array}{c}-0.062 \\
(0.119)\end{array}$ & $\begin{array}{l}-0.072 \\
(0.118)\end{array}$ & $\begin{array}{c}0.086 \\
(0.143)\end{array}$ & $\begin{array}{c}0.078 \\
(0.145)\end{array}$ & $\begin{array}{c}0.086 \\
(0.142)\end{array}$ & $\begin{array}{c}0.089 \\
(0.141)\end{array}$ \\
\hline Married male & $\begin{array}{c}0.191 \\
(0.108)\end{array}$ & $\begin{array}{l}0.188 \\
(0.107)\end{array}$ & $\begin{array}{l}0.316^{*} \\
(0.119)\end{array}$ & $\begin{array}{l}0.311^{*} \\
(0.120)\end{array}$ & $\begin{array}{l}-0.143 \\
(0.145)\end{array}$ & $\begin{array}{l}-0.151 \\
(0.148)\end{array}$ & $\begin{array}{c}-0.163 \\
(0.146)\end{array}$ & $\begin{array}{l}-0.147 \\
(0.145)\end{array}$ \\
\hline Spouse employed & $\begin{array}{l}-0.107 \\
(0.097)\end{array}$ & $\begin{array}{l}-0.076 \\
(0.094)\end{array}$ & $\begin{array}{l}-0.097 \\
(0.108)\end{array}$ & $\begin{array}{l}-0.078 \\
(0.105)\end{array}$ & $\begin{array}{c}-0.069 \\
(0.127)\end{array}$ & $\begin{array}{l}-0.066 \\
(0.128)\end{array}$ & $\begin{array}{l}-0.065 \\
(0.127)\end{array}$ & $\begin{array}{l}-0.069 \\
(0.126)\end{array}$ \\
\hline Primary school & $\begin{array}{l}-1.580^{*} \\
(0.221)\end{array}$ & $\begin{array}{c}-1.629^{*} \\
(0.233)\end{array}$ & $\begin{array}{l}-1.078^{*} \\
(0.240)\end{array}$ & $\begin{array}{l}-1.175^{*} \\
(0.239)\end{array}$ & $\begin{array}{c}-0.146 \\
(0.261)\end{array}$ & $\begin{array}{l}-0.084 \\
(0.333)\end{array}$ & $\begin{array}{c}-0.105 \\
(0.221)\end{array}$ & $\begin{array}{l}-0.164 \\
(0.219)\end{array}$ \\
\hline Incomplete high school & $\begin{array}{l}-1.146^{*} \\
(0.100)\end{array}$ & -1.183* & $\begin{array}{l}-0.791^{*} \\
(0.108)\end{array}$ & $\begin{array}{l}-0.865^{\star} \\
(0.107)\end{array}$ & $\begin{array}{l}-0.029 \\
(0.206)\end{array}$ & $\begin{array}{c}0.028 \\
(0.283)\end{array}$ & $\begin{array}{c}0.014 \\
(0.167)\end{array}$ & $\begin{array}{l}-0.045 \\
(0.162)\end{array}$ \\
\hline Complete high & $\begin{array}{c}-0.837^{*} \\
(0.079)\end{array}$ & $\begin{array}{c}-0.873^{*} \\
(0.082)\end{array}$ & $\begin{array}{c}-0.509^{*} \\
(0.087)\end{array}$ & $\begin{array}{l}-0.551^{*} \\
(0.086)\end{array}$ & $\begin{array}{l}-0.165 \\
(0.172)\end{array}$ & $\begin{array}{c}-0.119 \\
(0.239)\end{array}$ & $\begin{array}{l}-0.135 \\
(0.137)\end{array}$ & $\begin{array}{l}-0.177 \\
(0.133)\end{array}$ \\
\hline Incomplete college & $\begin{array}{c}-0.335^{\star} \\
(0.081)\end{array}$ & $\begin{array}{c}-0.361^{*} \\
(0.081)\end{array}$ & $\begin{array}{l}-0.162^{*} \\
(0.089)\end{array}$ & $\begin{array}{c}-0.195^{*} \\
(0.088)\end{array}$ & $\begin{array}{c}-0.129 \\
(0.136)\end{array}$ & $\begin{array}{c}-0.107 \\
(0.161)\end{array}$ & $\begin{array}{l}-0.127 \\
(0.129)\end{array}$ & $\begin{array}{l}-0.148 \\
(0.126)\end{array}$ \\
\hline Associate degree & $\begin{array}{l}-0.261^{*} \\
(0.111)\end{array}$ & $\begin{array}{l}-0.272^{*} \\
(0.111)\end{array}$ & $\begin{array}{c}0.003 \\
(0.124)\end{array}$ & $\begin{array}{c}-0.004 \\
(0.123)\end{array}$ & $\begin{array}{l}-0.143 \\
(0.178)\end{array}$ & $\begin{array}{l}-0.124 \\
(0.191)\end{array}$ & $\begin{array}{l}-0.159 \\
(0.175)\end{array}$ & $\begin{array}{l}-0.167 \\
(0.173)\end{array}$ \\
\hline Black & $\begin{array}{c}-0.257^{*} \\
(0.072)\end{array}$ & $\begin{array}{c}-0.255^{*} \\
(0.074)\end{array}$ & $\begin{array}{c}0.042 \\
(0.080)\end{array}$ & $\begin{array}{c}0.029 \\
(0.082)\end{array}$ & $\begin{array}{l}0.221^{*} \\
(0.101)\end{array}$ & $\begin{array}{c}0.233^{*} \\
(0.107)\end{array}$ & $\begin{array}{c}0.220^{*} \\
(0.097)\end{array}$ & $\begin{array}{c}0.222^{*} \\
(0.097)\end{array}$ \\
\hline
\end{tabular}




\begin{tabular}{|c|c|c|c|c|c|c|c|c|}
\hline Hispanic & $\begin{array}{l}-0.206^{*} \\
(0.090)\end{array}$ & $\begin{array}{l}-0.218^{*} \\
(0.090)\end{array}$ & $\begin{array}{c}0.085 \\
(0.099)\end{array}$ & $\begin{array}{c}0.095 \\
(0.099)\end{array}$ & $\begin{array}{c}0.128 \\
(0.117)\end{array}$ & $\begin{array}{c}0.136 \\
(0.119)\end{array}$ & $\begin{array}{c}0.122 \\
(0.117)\end{array}$ & $\begin{array}{c}0.126 \\
(0.116)\end{array}$ \\
\hline Home owner & $\begin{array}{c}0.081 \\
(0.054)\end{array}$ & $\begin{array}{c}0.078 \\
(0.053)\end{array}$ & $\begin{array}{l}-0.155^{*} \\
(0.061)\end{array}$ & $\begin{array}{l}-0.184^{*} \\
(0.060)\end{array}$ & $\begin{array}{l}-0.034 \\
(0.071)\end{array}$ & $\begin{array}{l}-0.037 \\
(0.073)\end{array}$ & $\begin{array}{l}-0.025 \\
(0.073)\end{array}$ & $\begin{array}{l}-0.034 \\
(0.073)\end{array}$ \\
\hline Immigrant & $\begin{array}{l}-0.036 \\
(0.091)\end{array}$ & $\begin{array}{l}-0.020 \\
(0.091)\end{array}$ & $\begin{array}{l}-0.123 \\
(0.099)\end{array}$ & $\begin{array}{l}-0.088 \\
(0.099)\end{array}$ & $\begin{array}{l}-0.301^{*} \\
(0.128)\end{array}$ & $\begin{array}{l}-0.303^{*} \\
(0.129)\end{array}$ & $\begin{array}{l}-0.300^{*} \\
(0.129)\end{array}$ & $\begin{array}{l}-0.297^{\star} \\
(0.129)\end{array}$ \\
\hline Con. employer & $\begin{array}{c}0.098 \\
(0.054)\end{array}$ & $\begin{array}{c}0.096 \\
(0.054)\end{array}$ & $\begin{array}{c}0.096 \\
(0.059)\end{array}$ & $\begin{array}{c}0.089 \\
(0.059)\end{array}$ & $\begin{array}{l}-0.032 \\
(0.075)\end{array}$ & $\begin{array}{l}-0.039 \\
(0.077)\end{array}$ & $\begin{array}{l}-0.0400 \\
(0.074)\end{array}$ & $\begin{array}{l}-0.033 \\
(0.074)\end{array}$ \\
\hline Con. public ea & $\begin{array}{l}0.199^{*} \\
(0.063)\end{array}$ & $\begin{array}{l}0.192^{\star} \\
(0.063)\end{array}$ & $\begin{array}{l}0.349^{*} \\
(0.070)\end{array}$ & $\begin{array}{l}0.326^{*} \\
(0.070)\end{array}$ & $\begin{array}{l}0.172^{*} \\
(0.086)\end{array}$ & $\begin{array}{c}0.163 \\
(0.090)\end{array}$ & $\begin{array}{c}0.149 \\
(0.089)\end{array}$ & $\begin{array}{c}0.163 \\
(0.087)\end{array}$ \\
\hline Con private ea & $\begin{array}{l}0.296^{*} \\
(0.092)\end{array}$ & $\begin{array}{l}0.287^{*} \\
(0.092)\end{array}$ & $\begin{array}{l}0.294^{*} \\
(0.102)\end{array}$ & $\begin{array}{l}0.290^{*} \\
(0.101)\end{array}$ & $\begin{array}{c}0.089 \\
(0.124)\end{array}$ & $\begin{array}{c}0.074 \\
(0.133)\end{array}$ & $\begin{array}{c}0.066 \\
(0.124)\end{array}$ & $\begin{array}{c}0.083 \\
(0.121)\end{array}$ \\
\hline Con. friend/rel. & $\begin{array}{c}0.019 \\
(0.076)\end{array}$ & $\begin{array}{c}0.032 \\
(0.075)\end{array}$ & $\begin{array}{c}0.065 \\
(0.083)\end{array}$ & $\begin{array}{c}0.079 \\
(0.083)\end{array}$ & $\begin{array}{c}0.177 \\
(0.102)\end{array}$ & $\begin{array}{c}0.175 \\
(0.103)\end{array}$ & $\begin{array}{c}0.163 \\
(0.103)\end{array}$ & $\begin{array}{c}0.168 \\
(0.102)\end{array}$ \\
\hline Con. school ec & $\begin{array}{c}0.032 \\
(0.143)\end{array}$ & $\begin{array}{c}0.044 \\
(0.142)\end{array}$ & $\begin{array}{c}0.059 \\
(0.160)\end{array}$ & $\begin{array}{c}0.081 \\
(0.159)\end{array}$ & $\begin{array}{c}0.039 \\
(0.192)\end{array}$ & $\begin{array}{c}0.032 \\
(0.194)\end{array}$ & $\begin{array}{c}0.038 \\
(0.194)\end{array}$ & $\begin{array}{c}0.049 \\
(0.192)\end{array}$ \\
\hline Sent resumes & $\begin{array}{l}0.359^{*} \\
(0.052)\end{array}$ & $\begin{array}{l}0.358^{*} \\
(0.053)\end{array}$ & $\begin{array}{l}0.367^{*} \\
(0.058)\end{array}$ & $\begin{array}{l}0.374^{*} \\
(0.057)\end{array}$ & $\begin{array}{c}0.082 \\
(0.080)\end{array}$ & $\begin{array}{c}0.067 \\
(0.094)\end{array}$ & $\begin{array}{c}0.056 \\
(0.078)\end{array}$ & $\begin{array}{c}0.077 \\
(0.077)\end{array}$ \\
\hline Check union & $\begin{array}{c}0.063 \\
(0.168)\end{array}$ & $\begin{array}{c}0.062 \\
(0.168)\end{array}$ & $\begin{array}{c}0.032 \\
(0.187)\end{array}$ & $\begin{array}{c}0.052 \\
(0.186)\end{array}$ & $\begin{array}{c}0.278 \\
(0.211)\end{array}$ & $\begin{array}{c}0.277 \\
(0.213)\end{array}$ & $\begin{array}{c}0.274 \\
(0.212)\end{array}$ & $\begin{array}{c}0.273 \\
(0.211)\end{array}$ \\
\hline Used ads & $\begin{array}{l}0.297^{*} \\
(0.068)\end{array}$ & $\begin{array}{l}0.299^{*} \\
(0.069)\end{array}$ & $\begin{array}{l}0.336^{*} \\
(0.076)\end{array}$ & $\begin{array}{l}0.351^{*} \\
(0.076)\end{array}$ & $\begin{array}{c}0.128 \\
(0.102)\end{array}$ & $\begin{array}{c}0.115 \\
(0.114)\end{array}$ & $\begin{array}{c}0.115 \\
(0.104)\end{array}$ & $\begin{array}{c}0.139 \\
(0.102)\end{array}$ \\
\hline Other active & $\begin{array}{c}0.426^{\star} \\
(0.103)\end{array}$ & $\begin{array}{c}0.429^{*} \\
(0.103)\end{array}$ & $\begin{array}{l}0.333^{*} \\
(0.113)\end{array}$ & $\begin{array}{l}0.356^{*} \\
(0.112)\end{array}$ & $\begin{array}{l}-0.039 \\
(0.161)\end{array}$ & $\begin{array}{l}-0.060 \\
(0.178)\end{array}$ & $\begin{array}{l}-0.065 \\
(0.157)\end{array}$ & $\begin{array}{c}-0.039 \\
(0.156)\end{array}$ \\
\hline Spouse use & $\begin{array}{l}0.243^{*} \\
(0.101)\end{array}$ & & $\begin{array}{c}0.162 \\
(0.112)\end{array}$ & & & & & \\
\hline Child use & $\begin{array}{l}-0.063 \\
(0.109)\end{array}$ & & $\begin{array}{c}0.145 \\
(0.117)\end{array}$ & & & & & \\
\hline Parent use & $\begin{array}{c}0.183 \\
(0.109)\end{array}$ & & $\begin{array}{l}-0.089 \\
(0.116)\end{array}$ & & & & & \\
\hline Sibling use & $\begin{array}{c}0.156 \\
(0.118)\end{array}$ & & $\begin{array}{l}0.271^{*} \\
(0.124)\end{array}$ & & & & & \\
\hline Other use & $\begin{array}{l}0.500^{*} \\
(0.098)\end{array}$ & & $\begin{array}{l}0.547^{*} \\
(0.106)\end{array}$ & & & & & \\
\hline State access rate & & $\begin{array}{l}0.891^{*} \\
(0.453)\end{array}$ & & $\begin{array}{l}-0.155 \\
(0.495)\end{array}$ & & & & \\
\hline State mean cost & & $\begin{array}{l}-0.058^{*} \\
(0.022)\end{array}$ & & $\begin{array}{l}-0.063^{*} \\
(0.024)\end{array}$ & & & & \\
\hline State long-distance & & $\begin{array}{c}0.251 \\
(1.326)\end{array}$ & & $\begin{array}{l}-0.527 \\
(1.423)\end{array}$ & & & & \\
\hline Constant & $\begin{array}{c}-1.498^{*} \\
(0.231)\end{array}$ & $\begin{array}{l}-0.788 \\
(0.484)\end{array}$ & $\begin{array}{l}-2.225^{\star} \\
(0.256)\end{array}$ & $\begin{array}{c}-1.052^{*} \\
(0.523)\end{array}$ & & & & \\
\hline Net access & & & $\begin{array}{l}1.491^{*} \\
(0.071)\end{array}$ & $\begin{array}{l}1.490^{*} \\
(0.068)\end{array}$ & & & $\begin{array}{l}-0.118 \\
(0.202)\end{array}$ & $\begin{array}{l}-0.004 \\
(0.201)\end{array}$ \\
\hline Rho & & & & & $\begin{array}{c}0.207 \\
(0.240)\end{array}$ & $\begin{array}{c}0.111 \\
(0.401)\end{array}$ & $\begin{array}{c}0.127 \\
(0.262)\end{array}$ & $\begin{array}{c}0.282 \\
(0.223)\end{array}$ \\
\hline Log likelihood & & & & & -3784.65 & -3795.74 & -3463.49 & -3477.02 \\
\hline
\end{tabular}

Note: Standard errors are in parentheses. * indicates significance at the $5 \%$ level. The sample size for all specifications is 4139 . 


\section{References}

Addison, J. and P. Portugal. "Job Search Methods and Outcomes" Institute for the Study of Labor (IZA), Discussion Paper No. 349. (August 2001).

Autor, D. "Wiring the Labor Market" Journal of Economic Perspectives 15 (1) (Winter 2001): $25-40$.

Bortnick, S. M and M. H. Ports, "Job Search Methods and Results: Tracking the Unemployed" Monthly Labor Review; 115(12), December 1992, pages 29-35.

Brown, Jeffrey and Austan Goolsbee. "Does the Internet Make Markets More Competitive? Evidence from the Life Insurance Industry" Journal of Political Economy 110(3) (June 2002): 481-507.

Brynjolfsson, Erik and Michael D. Smith, "Frictionless Commerce? A Comparison of Internet and Conventional Retailers". Management Science 46(4), (April 2000): 563-585.

Carlton, Dennis W. and Judith A. Chevalier. "Free Riding and Sales Strategies for the Internet" NBER Working Paper No. W8067, January 2001.

Crossley, T., S. Jones and P. Kuhn. "Gender Differences in Displacement Costs: Evidence and Implications" Journal of Human Resources 19 (Spring 1994): 461-480

Fairlie, Robert W. "Race and the Digital Divide" unpublished paper, University of California, Santa Cruz, December 2001.

Goolsbee, Austan, and Peter J. Klenow. "Evidence on Learning and Network Externalities in the Diffusion of Home Computers” NBER Working Paper No.w7329, September 1999.

Granovetter, Mark. Getting a Job: A Study of Contacts and Careers. $\left(2^{\text {nd }}\right.$ edition $)$. Chicago: University of Chicago Press, 1995.

Greene, W. "Gender Economics Courses in Liberal Arts Colleges: Further Results". Journal of Economic Education 29(4) (1998): 291-300.

Greene, W. Econometric Analysis (4th ${ }^{\text {th }}$ edition), Upper Saddle River, NJ: Prentice-Hall, 2000.

Han, A. and H. Hausman. "Flexible Parametric Estimation of Duration and Competing Risk Models". Journal of Applied Econometrics 5 (1) (January-March 1990): 1-28.

Heckman, J. and B. Singer (1984). "A Method for Minimizing the Impact of Distributional Assumptions in Econometric Models for Duration Data” Econometrica 52(2): 271-320.

Holzer, H. J. "Informal Job Search and Black Youth Unemployment". American Economic Review 77 (June 1987): 446-52.

Holzer, H. J. "Search Method Use by Unemployed Youth”. Journal of Labor Economics; 6(1), January 1988, pages 1-20.

Kiefer, N. "Economic Duration Data and Hazard Functions" Journal of Economic Literature 26 (2) (June 1988): 646-679. 
Krueger, Alan B. "The Internet is Lowering the Cost of Advertising and Searching for Jobs". New York Times July 20, 2000, p. C2.

Kuhn, P. "Policies for an Internet Labour Market". Policy Options, October 2000: pp. 42-47.

Kuhn, P. and M. Skuterud, "Job Search Methods: Internet versus Traditional". Monthly Labor Review, October 2000, pp. 3-11.

Lancaster, Tony (1979). "Econometric Methods for the Duration of Unemployment" Econometrica 47(4): 939-56.

Lang, Kevin. "Panel: Modelling How Search-Matching Technologies Affect Labor Markets", talk given to IRPP and CERF conference on Creating Canada's Advantage in an Information Age, May 2000.

Madrian, Brigitte and Lars Lefgren (1999). "A Note on Longitudinally Matching Current Population Survey (CPS) Respondents” NBER Technical Working Paper Series no. 247.

Meyer, Bruce. "Unemployment Insurance and Unemployment Spells". Econometrica 58 (July 1990): 757-782.

Mortensen, Dale T. "Panel: Modeling How Search-Matching Technologies Affect Labor Markets", talk given to the IRPP and CERF conference on Creating Canada's Advantage in an Information Age, May 2000.

Osberg, L. "Fishing in Different Pools: Job Search Strategies and Job-Finding Success in Canada in the Early 1980s". Journal of Labor Economics; 11(2), April 1993, pages 348-86.

Skuterud, Mikal "Causes and Consequences of the Upward Trend in On-the-Job Search: 19761995", unpublished paper, McMaster University, 2001.

Thomas, J. M. "Public Employment Agencies and Unemployment Spells: Reconciling the Experimental and Nonexperimental Evidence". Industrial and Labor Relations Review; 50(4), July 1997, pages 667-83. 
Table 1: Fraction of persons with internet access and engaging in internet job search, by labor force status, December 1998 and August 2000.

\begin{tabular}{|c|c|c|c|c|c|c|}
\hline & \multicolumn{2}{|c|}{$\begin{array}{l}\text { Fraction with home } \\
\text { internet access }\end{array}$} & \multicolumn{2}{|c|}{$\begin{array}{l}\text { Fraction looking for work } \\
\text { on line }\end{array}$} & \multicolumn{2}{|c|}{$\begin{array}{l}\text { Fraction looking for work } \\
\text { on line, given home } \\
\text { internet access }\end{array}$} \\
\hline & 1998 & 2000 & 1998 & 2000 & 1998 & 2000 \\
\hline $\begin{array}{l}\text { Employed } \\
\text { - at work } \\
\text { - absent }\end{array}$ & $\begin{array}{l}.347 \\
.339\end{array}$ & $\begin{array}{l}.521 \\
.611\end{array}$ & $\begin{array}{l}0.071 \\
0.070\end{array}$ & $\begin{array}{l}0.113 \\
0.105\end{array}$ & $\begin{array}{l}0.159 \\
0.166\end{array}$ & $\begin{array}{l}0.183 \\
0.151\end{array}$ \\
\hline $\begin{array}{l}\text { Unemployed } \\
\text { - on layoff } \\
\text { - jobseeker }\end{array}$ & $\begin{array}{l}.165 \\
.223\end{array}$ & $\begin{array}{l}.396 \\
.394\end{array}$ & $\begin{array}{l}0.048 \\
0.150\end{array}$ & $\begin{array}{l}0.103 \\
0.255\end{array}$ & $\begin{array}{l}0.176 \\
0.495\end{array}$ & $\begin{array}{l}0.207 \\
0.541\end{array}$ \\
\hline $\begin{array}{l}\text { Not in LF } \\
\text { - retired } \\
\text { - disabled } \\
\text { - other }\end{array}$ & $\begin{array}{l}.122 \\
.105 \\
.319\end{array}$ & $\begin{array}{l}.238 \\
.204 \\
.465\end{array}$ & $\begin{array}{l}0.003 \\
0.014 \\
0.038\end{array}$ & $\begin{array}{l}0.005 \\
0.022 \\
0.063\end{array}$ & $\begin{array}{l}0.023 \\
0.104 \\
0.090\end{array}$ & $\begin{array}{l}0.021 \\
0.097 \\
0.117\end{array}$ \\
\hline Total & .294 & .457 & 0.055 & 0.089 & 0.146 & 0.165 \\
\hline
\end{tabular}

Notes:

1. Does not equal the ratio of previous columns because some individuals without home internet access search on line. 


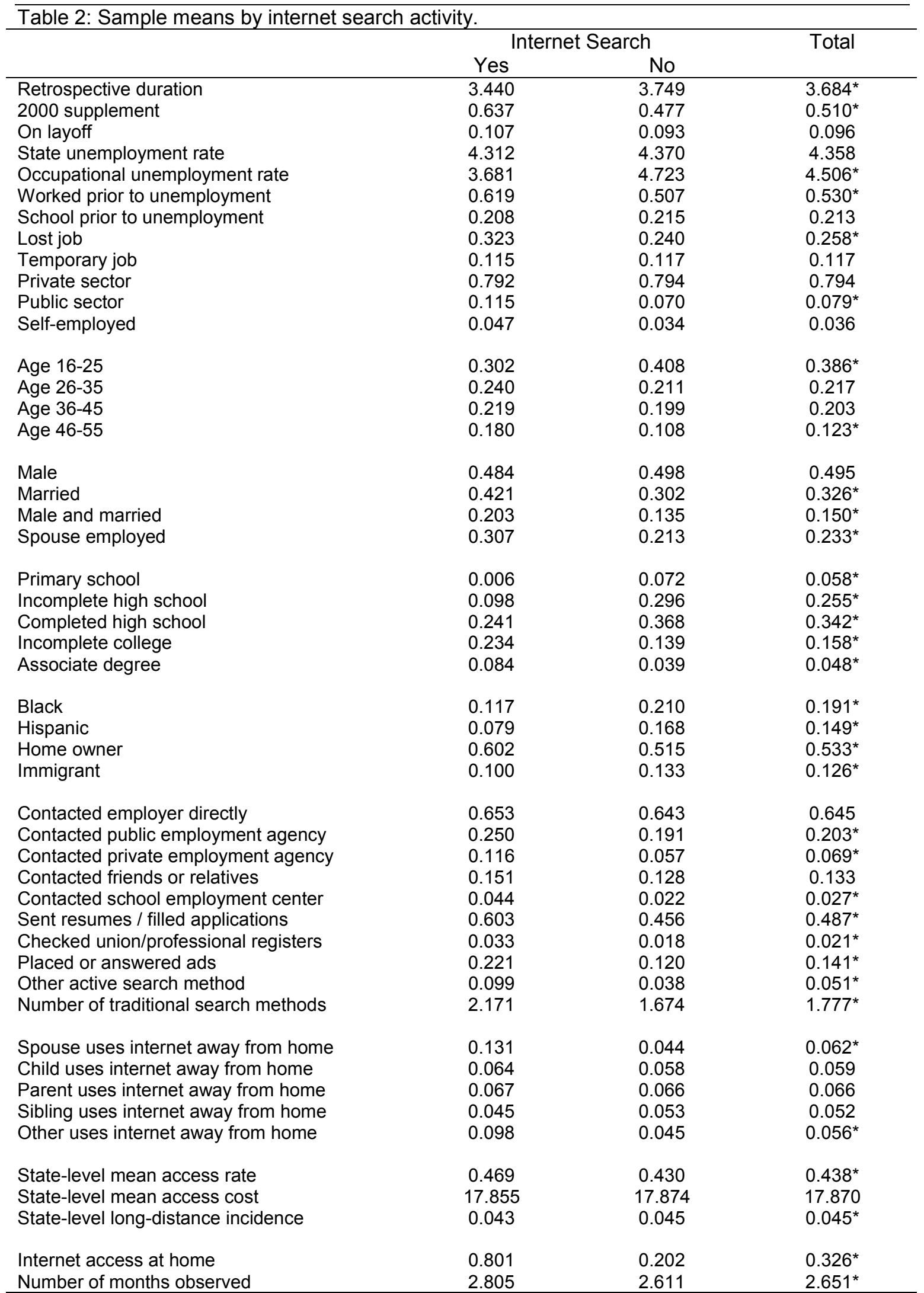

Note: * indicates if means are statistically different at a $5 \%$ significance level which is obtained by regressing each variable on a constant and the internet search dummy variable. Sample sizes are 860 internet searchers and 3279 non-internet searchers. 
Table 3: Percent of unemployed sample observed in employment in subsequent months by internet search activity.

\begin{tabular}{|c|c|c|c|}
\hline & \multicolumn{2}{|c|}{ Internet Search } & \multirow[t]{2}{*}{ Total } \\
\hline & Yes & No & \\
\hline $\begin{array}{l}\text { Employed in the month following the } \\
\text { Computer/Internet Supplement } \\
\text { (share of persons observed at that date) }\end{array}$ & 0.298 & 0.289 & 0.291 \\
\hline $\begin{array}{l}\text { Employed } 2 \text { months after } \\
\text { Computer/Internet Supplement } \\
\text { (share of persons observed at that date) }\end{array}$ & 0.413 & 0.365 & 0.375 \\
\hline $\begin{array}{l}\text { Employed } 12 \text { months after } \\
\text { Computer/Internet Supplement } \\
\text { (share of persons observed at that date) }\end{array}$ & 0.646 & 0.533 & $0.559^{*}$ \\
\hline $\begin{array}{l}\text { Observed in Employment, in any post- } \\
\text { supplement month } \\
\text { (share of all observations) }\end{array}$ & 0.614 & 0.545 & $0.559^{*}$ \\
\hline $\begin{array}{l}\text { Notes: } \\
\text { Overall sample size is } 860 \text { internet sear } \\
\text { * indicates if means are statistically differ } \\
\text { regressing each variable on a constant a }\end{array}$ & intern & level. & ed by \\
\hline
\end{tabular}


Table 4: Probit estimates of the probability of being employed in 12 months.

Home Internet Access Control

\begin{tabular}{|c|c|c|c|c|c|c|c|c|}
\hline & No & Yes & No & Yes & No & Yes & No & Yes \\
\hline & $(1)$ & $(2)$ & (3) & $(4)$ & $(5)$ & $(6)$ & $(7)$ & $(8)$ \\
\hline Net search & $\begin{array}{l}0.291^{*} \\
(0.083)\end{array}$ & $\begin{array}{l}0.230^{*} \\
(0.099)\end{array}$ & $\begin{array}{l}0.193^{*} \\
(0.089)\end{array}$ & $\begin{array}{c}0.140 \\
(0.103)\end{array}$ & $\begin{array}{c}0.062 \\
(0.095)\end{array}$ & $\begin{array}{c}0.035 \\
(0.107)\end{array}$ & $\begin{array}{c}0.031 \\
(0.097)\end{array}$ & $\begin{array}{l}-0.005 \\
(0.109)\end{array}$ \\
\hline Retrospective duration & & & $\begin{array}{l}-0.030^{*} \\
(0.007)\end{array}$ & $\begin{array}{l}-0.030^{*} \\
(0.007)\end{array}$ & $\begin{array}{l}-0.027^{*} \\
(0.007)\end{array}$ & $\begin{array}{c}-0.027^{*} \\
(0.007)\end{array}$ & $\begin{array}{l}-0.029^{*} \\
(0.007)\end{array}$ & $\begin{array}{l}-0.029^{*} \\
(0.007)\end{array}$ \\
\hline 2000 supplement & & & $\begin{array}{l}-0.111 \\
(0.074)\end{array}$ & $\begin{array}{l}-0.119 \\
(0.074)\end{array}$ & $\begin{array}{l}-0.100 \\
(0.075)\end{array}$ & $\begin{array}{l}-0.105 \\
(0.076)\end{array}$ & $\begin{array}{l}-0.108 \\
(0.076)\end{array}$ & $\begin{array}{l}-0.115 \\
(0.077)\end{array}$ \\
\hline On layoff & & & $\begin{array}{l}0.337^{*} \\
(0.133)\end{array}$ & $\begin{array}{l}0.336^{*} \\
(0.133)\end{array}$ & $\begin{array}{l}0.328^{*} \\
(0.135)\end{array}$ & $\begin{array}{l}0.328^{*} \\
(0.135)\end{array}$ & $\begin{array}{l}0.316^{*} \\
(0.138)\end{array}$ & $\begin{array}{l}0.315^{*} \\
(0.137)\end{array}$ \\
\hline State ur & & & $\begin{array}{c}0.036 \\
(0.037)\end{array}$ & $\begin{array}{c}0.038 \\
(0.038)\end{array}$ & $\begin{array}{c}0.040 \\
(0.039)\end{array}$ & $\begin{array}{c}0.041 \\
(0.039)\end{array}$ & $\begin{array}{c}0.034 \\
(0.039)\end{array}$ & $\begin{array}{c}0.034 \\
(0.040)\end{array}$ \\
\hline Occupation ur & & & $\begin{array}{l}-0.064^{*} \\
(0.019)\end{array}$ & $\begin{array}{l}-0.062^{*} \\
(0.019)\end{array}$ & $\begin{array}{l}-0.044^{*} \\
(0.021)\end{array}$ & $\begin{array}{l}-0.044^{*} \\
(0.021)\end{array}$ & $\begin{array}{l}-0.044^{*} \\
(0.021)\end{array}$ & $\begin{array}{l}-0.043^{*} \\
(0.021)\end{array}$ \\
\hline Worked before u & & & $\begin{array}{l}0.418^{*} \\
(0.119)\end{array}$ & $\begin{array}{l}0.420^{*} \\
(0.119)\end{array}$ & $\begin{array}{l}0.414^{*} \\
(0.122)\end{array}$ & $\begin{array}{l}0.415^{\star} \\
(0.122)\end{array}$ & $\begin{array}{l}0.418^{*} \\
(0.123)\end{array}$ & $\begin{array}{l}0.420^{*} \\
(0.123)\end{array}$ \\
\hline School before u & & & $\begin{array}{l}0.261^{*} \\
(0.108)\end{array}$ & $\begin{array}{l}0.250^{*} \\
(0.108)\end{array}$ & $\begin{array}{l}0.271^{*} \\
(0.121)\end{array}$ & $\begin{array}{l}0.266^{*} \\
(0.121)\end{array}$ & $\begin{array}{l}0.258^{*} \\
(0.122)\end{array}$ & $\begin{array}{l}0.251^{*} \\
(0.122)\end{array}$ \\
\hline Lost job & & & $\begin{array}{c}0.019 \\
(0.120)\end{array}$ & $\begin{array}{c}0.018 \\
(0.121)\end{array}$ & $\begin{array}{c}0.027 \\
(0.123)\end{array}$ & $\begin{array}{c}0.027 \\
(0.123)\end{array}$ & $\begin{array}{l}-0.010 \\
(0.125)\end{array}$ & $\begin{array}{l}-0.010 \\
(0.125)\end{array}$ \\
\hline Temporary job & & & $\begin{array}{l}-0.220 \\
(0.140)\end{array}$ & $\begin{array}{l}-0.215 \\
(0.140)\end{array}$ & $\begin{array}{l}-0.195 \\
(0.142)\end{array}$ & $\begin{array}{l}-0.191 \\
(0.142)\end{array}$ & $\begin{array}{l}-0.246 \\
(0.145)\end{array}$ & $\begin{array}{l}-0.241 \\
(0.145)\end{array}$ \\
\hline Private sector & & & $\begin{array}{l}0.494^{*} \\
(0.142)\end{array}$ & $\begin{array}{c}0.489^{*} \\
(0.142)\end{array}$ & $\begin{array}{l}0.422^{*} \\
(0.148)\end{array}$ & $\begin{array}{l}0.419^{*} \\
(0.148)\end{array}$ & $\begin{array}{c}0.440^{*} \\
(0.149)\end{array}$ & $\begin{array}{c}0.437^{*} \\
(0.149)\end{array}$ \\
\hline Public sector & & & $\begin{array}{c}0.188 \\
(0.186)\end{array}$ & $\begin{array}{c}0.181 \\
(0.186)\end{array}$ & $\begin{array}{c}0.089 \\
(0.195)\end{array}$ & $\begin{array}{c}0.087 \\
(0.195)\end{array}$ & $\begin{array}{c}0.132 \\
(0.196)\end{array}$ & $\begin{array}{c}0.130 \\
(0.196)\end{array}$ \\
\hline Self-employed & & & $\begin{array}{c}0.199 \\
(0.231)\end{array}$ & $\begin{array}{c}0.188 \\
(0.232)\end{array}$ & $\begin{array}{c}0.153 \\
(0.241)\end{array}$ & $\begin{array}{c}0.151 \\
(0.241)\end{array}$ & $\begin{array}{c}0.219 \\
(0.242)\end{array}$ & $\begin{array}{c}0.216 \\
(0.243)\end{array}$ \\
\hline Age $16-25$ & & & & & $\begin{array}{l}0.571^{*} \\
(0.160)\end{array}$ & $\begin{array}{c}0.572^{*} \\
(0.160)\end{array}$ & $\begin{array}{l}0.584^{*} \\
(0.161)\end{array}$ & $\begin{array}{c}0.585^{*} \\
(0.161)\end{array}$ \\
\hline Age 26-35 & & & & & $\begin{array}{l}0.466^{*} \\
(0.153)\end{array}$ & $\begin{array}{l}0.471^{*} \\
(0.154)\end{array}$ & $\begin{array}{l}0.443^{*} \\
(0.155)\end{array}$ & $\begin{array}{l}0.450^{*} \\
(0.156)\end{array}$ \\
\hline Age $36-45$ & & & & & $\begin{array}{l}0.507^{*} \\
(0.149)\end{array}$ & $\begin{array}{l}0.511^{*} \\
(0.149)\end{array}$ & $\begin{array}{l}0.511^{*} \\
(0.151)\end{array}$ & $\begin{array}{l}0.516^{*} \\
(0.151)\end{array}$ \\
\hline Age 46-55 & & & & & $\begin{array}{c}0.242 \\
(0.155)\end{array}$ & $\begin{array}{c}0.243 \\
(0.155)\end{array}$ & $\begin{array}{c}0.241 \\
(0.157)\end{array}$ & $\begin{array}{c}0.243 \\
(0.157)\end{array}$ \\
\hline Male & & & & & $\begin{array}{l}-0.187^{*} \\
(0.094)\end{array}$ & $\begin{array}{c}-0.190^{*} \\
(0.095)\end{array}$ & $\begin{array}{l}-0.175 \\
(0.095)\end{array}$ & $\begin{array}{l}-0.179 \\
(0.095)\end{array}$ \\
\hline Married & & & & & $\begin{array}{c}0.032 \\
(0.151)\end{array}$ & $\begin{array}{c}0.027 \\
(0.151)\end{array}$ & $\begin{array}{c}0.031 \\
(0.153)\end{array}$ & $\begin{array}{c}0.024 \\
(0.153)\end{array}$ \\
\hline Married male & & & & & $\begin{array}{l}0.336^{*} \\
(0.154)\end{array}$ & $\begin{array}{l}0.339^{*} \\
(0.154)\end{array}$ & $\begin{array}{l}0.319^{*} \\
(0.157)\end{array}$ & $\begin{array}{l}0.322^{*} \\
(0.157)\end{array}$ \\
\hline Spouse employed & & & & & $\begin{array}{l}-0.081 \\
(0.135)\end{array}$ & $\begin{array}{l}-0.082 \\
(0.135)\end{array}$ & $\begin{array}{l}-0.077 \\
(0.137)\end{array}$ & $\begin{array}{l}-0.079 \\
(0.137)\end{array}$ \\
\hline
\end{tabular}


Primary school

Incomplete high

Complete high

Incomplete college

Associate degree

Black

Hispanic

Home owner

Immigrant

Contact employer

Contact public ea

Contact private ea

Contact friend/relative

Contact school ec

Sent resumes

Check union

Used ads

Other active

Constant

Net access

$$
\begin{array}{cccc}
0.083^{*} & 0.064 & -0.297 & -0.326 \\
(0.039) & (0.043) & (0.244) & (0.246) \\
& 0.099 & & 0.092 \\
& (0.087) & & (0.090)
\end{array}
$$

$\begin{array}{cccc}-0.295 & -0.286 & -0.264 & -0.251 \\ (0.204) & (0.205) & (0.207) & (0.208) \\ -0.443^{*} & -0.439^{*} & -0.414^{*} & -0.407^{*} \\ (0.144) & (0.144) & (0.147) & (0.147) \\ -0.200 & -0.190 & -0.170 & -0.160 \\ (0.126) & (0.127) & (0.129) & (0.130) \\ -0.087 & -0.083 & -0.061 & -0.055 \\ (0.136) & (0.136) & (0.138) & (0.138) \\ 0.153 & 0.157 & 0.171 & 0.177 \\ (0.187) & (0.187) & (0.190) & (0.190)\end{array}$

$\begin{array}{llll}-0.267^{*} & -0.260^{*} & -0.280^{*} & -0.272^{*}\end{array}$

$\begin{array}{llll}(0.095) & (0.095) & (0.096) & (0.097)\end{array}$

$\begin{array}{llll}0.008 & 0.016 & 0.007 & 0.017\end{array}$

$\begin{array}{llll}(0.114) & (0.115) & (0.116) & (0.117)\end{array}$

$\begin{array}{llll}0.071 & 0.067 & 0.077 & 0.071\end{array}$

$\begin{array}{llll}(0.078) & (0.079) & (0.079) & (0.080)\end{array}$

$\begin{array}{llll}0.011 & 0.008 & 0.057 & 0.051\end{array}$

$(0.117) \quad(0.117) \quad(0.118) \quad(0.118)$

$0.159 * \quad 0.160 *$

$(0.079) \quad(0.079)$

$0.257^{*} \quad 0.262^{*}$

$(0.097) \quad(0.098)$

$0.247 \quad 0.249$

$(0.153) \quad(0.153)$

$-0.146 \quad-0.143$

$(0.111) \quad(0.111)$

$-0.245 \quad-0.243$

$(0.220) \quad(0.220)$

$0.220^{*} \quad 0.220^{*}$

$(0.077) \quad(0.077)$

$-0.139 \quad-0.142$

$(0.292) \quad(0.292)$

$-0.158 \quad-0.157$

$(0.108) \quad(0.108)$

$0.281 \quad 0.284$

$(0.179) \quad(0.180)$

$\begin{array}{llll}-0.517 & -0.531 & -0.744^{*} & -0.766^{*} \\ (0.308) & (0.309) & (0.320) & (0.322)\end{array}$

$0.052 \quad 0.069$

(0.096)

Log likelihood $\begin{array}{llll}-916.12 & -915.47 & -862.26 & -861.7\end{array}$

$\begin{array}{lll}-840.15 & -840.00 & -827.22\end{array}$ $-826.97$ Note: Standard errors are in parentheses. ${ }^{*}$ indicates significance at the $5 \%$ level. The sample size for all specifications is 1344 . 
Table 5: Ordered Extreme-Value and Ordered-Probit Models of Unemployment Duration. ${ }^{1}$

\begin{tabular}{|c|c|c|c|c|}
\hline \multirow[b]{2}{*}{ Access Control } & \multicolumn{2}{|c|}{ Ordered Extreme-Value } & \multicolumn{2}{|c|}{ Ordered Probit } \\
\hline & No & Yes & No & Yes \\
\hline & $(1)$ & $(2)$ & $(3)$ & $(4)$ \\
\hline Internet search & $\begin{array}{c}0.170^{*} \\
(0.074)\end{array}$ & $\begin{array}{c}0.309^{*} \\
(0.086)\end{array}$ & $\begin{array}{c}0.144^{*} \\
(0.067)\end{array}$ & $\begin{array}{c}0.269^{*} \\
(0.077)\end{array}$ \\
\hline Retrospective duration & $\begin{array}{c}0.030^{*} \\
(0.005)\end{array}$ & $\begin{array}{c}0.030^{*} \\
(0.005)\end{array}$ & $\begin{array}{l}0.030^{*} \\
(0.005)\end{array}$ & $\begin{array}{l}0.030^{*} \\
(0.005)\end{array}$ \\
\hline 2000 Supplement & $\begin{array}{c}-0.310^{*} \\
(0.061)\end{array}$ & $\begin{array}{l}-0.280^{*} \\
(0.062)\end{array}$ & $\begin{array}{l}-0.244^{*} \\
(0.054)\end{array}$ & $\begin{array}{l}-0.215^{\star} \\
(0.055)\end{array}$ \\
\hline On layoff & $\begin{array}{c}-0.186 \\
(0.097)\end{array}$ & $\begin{array}{c}-0.183 \\
(0.097)\end{array}$ & $\begin{array}{l}-0.155 \\
(0.087)\end{array}$ & $\begin{array}{c}-0.154 \\
(0.087)\end{array}$ \\
\hline State unemployment rate & $\begin{array}{l}0.083^{*} \\
(0.031)\end{array}$ & $\begin{array}{l}0.088^{*} \\
(0.031)\end{array}$ & $\begin{array}{l}0.077^{*} \\
(0.028)\end{array}$ & $\begin{array}{c}0.082^{*} \\
(0.028)\end{array}$ \\
\hline Occupation unemployment rate & $\begin{array}{c}0.005 \\
(0.016)\end{array}$ & $\begin{array}{c}0.002 \\
(0.016)\end{array}$ & $\begin{array}{c}0.009 \\
(0.015)\end{array}$ & $\begin{array}{c}0.007 \\
(0.015)\end{array}$ \\
\hline Worked before unemployment & $\begin{array}{c}0.005 \\
(0.099)\end{array}$ & $\begin{array}{l}-0.014 \\
(0.099)\end{array}$ & $\begin{array}{c}0.022 \\
(0.086)\end{array}$ & $\begin{array}{c}0.007 \\
(0.086)\end{array}$ \\
\hline School before unemployment & $\begin{array}{c}0.097 \\
(0.102)\end{array}$ & $\begin{array}{c}0.093 \\
(0.102)\end{array}$ & $\begin{array}{c}0.079 \\
(0.091)\end{array}$ & $\begin{array}{c}0.082 \\
(0.091)\end{array}$ \\
\hline Lost job & $\begin{array}{l}0.200^{*} \\
(0.093)\end{array}$ & $\begin{array}{l}0.212^{*} \\
(0.093)\end{array}$ & $\begin{array}{l}0.174^{*} \\
(0.083)\end{array}$ & $\begin{array}{c}0.180^{*} \\
(0.083)\end{array}$ \\
\hline Temporary job & $\begin{array}{c}0.026 \\
(0.112)\end{array}$ & $\begin{array}{c}0.021 \\
(0.113)\end{array}$ & $\begin{array}{c}0.031 \\
(0.098)\end{array}$ & $\begin{array}{c}0.026 \\
(0.098)\end{array}$ \\
\hline Private sector & $\begin{array}{c}-0.090 \\
(0.134)\end{array}$ & $\begin{array}{l}-0.067 \\
(0.134)\end{array}$ & $\begin{array}{c}-0.112 \\
(0.121)\end{array}$ & $\begin{array}{c}-0.087 \\
(0.122)\end{array}$ \\
\hline Public sector & $\begin{array}{l}-0.360^{*} \\
(0.170)\end{array}$ & $\begin{array}{l}-0.343^{*} \\
(0.171)\end{array}$ & $\begin{array}{l}-0.319^{*} \\
(0.151)\end{array}$ & $\begin{array}{l}-0.301^{*} \\
(0.152)\end{array}$ \\
\hline Self-employed & $\begin{array}{l}-0.355 \\
(0.207)\end{array}$ & $\begin{array}{l}-0.327 \\
(0.207)\end{array}$ & $\begin{array}{l}-0.396^{\star} \\
(0.180)\end{array}$ & $\begin{array}{c}-0.372^{*} \\
(0.181)\end{array}$ \\
\hline Age $16-25$ & $\begin{array}{c}-0.374^{*} \\
(0.135)\end{array}$ & $\begin{array}{c}-0.359^{*} \\
(0.135)\end{array}$ & $\begin{array}{c}-0.347^{\star} \\
(0.123)\end{array}$ & $\begin{array}{l}-0.337^{*} \\
(0.124)\end{array}$ \\
\hline Age 26-35 & $\begin{array}{l}-0.306^{*} \\
(0.130)\end{array}$ & $\begin{array}{l}-0.312^{*} \\
(0.130)\end{array}$ & $\begin{array}{l}-0.291^{*} \\
(0.119)\end{array}$ & $\begin{array}{l}-0.302^{*} \\
(0.120)\end{array}$ \\
\hline Age $36-45$ & $\begin{array}{c}-0.199 \\
(0.128)\end{array}$ & $\begin{array}{l}-0.200 \\
(0.128)\end{array}$ & $\begin{array}{c}-0.184 \\
(0.117)\end{array}$ & $\begin{array}{c}-0.188 \\
(0.118)\end{array}$ \\
\hline Age 46-55 & $\begin{array}{l}-0.008 \\
(0.132)\end{array}$ & $\begin{array}{l}-0.014 \\
(0.132)\end{array}$ & $\begin{array}{c}0.000 \\
(0.123)\end{array}$ & $\begin{array}{l}-0.004 \\
(0.123)\end{array}$ \\
\hline Male & $\begin{array}{c}0.028 \\
(0.074)\end{array}$ & $\begin{array}{c}0.052 \\
(0.075)\end{array}$ & $\begin{array}{c}0.025 \\
(0.066)\end{array}$ & $\begin{array}{c}0.041 \\
(0.067)\end{array}$ \\
\hline Married & $\begin{array}{c}0.044 \\
(0.124)\end{array}$ & $\begin{array}{c}0.063 \\
(0.124)\end{array}$ & $\begin{array}{c}0.052 \\
(0.110)\end{array}$ & $\begin{array}{c}0.067 \\
(0.110)\end{array}$ \\
\hline Married male & $\begin{array}{l}-0.169 \\
(0.124)\end{array}$ & $\begin{array}{l}-0.205 \\
(0.124)\end{array}$ & $\begin{array}{l}-0.153 \\
(0.111)\end{array}$ & $\begin{array}{c}-0.173 \\
(0.111)\end{array}$ \\
\hline Spouse employed & $\begin{array}{c}0.036 \\
(0.110)\end{array}$ & $\begin{array}{c}0.050 \\
(0.111)\end{array}$ & $\begin{array}{c}0.019 \\
(0.098)\end{array}$ & $\begin{array}{c}0.028 \\
(0.098)\end{array}$ \\
\hline Primary school & $\begin{array}{l}-0.005 \\
(0.169)\end{array}$ & $\begin{array}{l}-0.071 \\
(0.170)\end{array}$ & $\begin{array}{c}0.009 \\
(0.149)\end{array}$ & $\begin{array}{c}-0.052 \\
(0.151)\end{array}$ \\
\hline Incomplete high & $\begin{array}{c}0.092 \\
(0.115)\end{array}$ & $\begin{array}{c}0.041 \\
(0.116)\end{array}$ & $\begin{array}{c}0.082 \\
(0.104)\end{array}$ & $\begin{array}{c}0.036 \\
(0.105)\end{array}$ \\
\hline Complete high & $\begin{array}{c}0.003 \\
(0.098)\end{array}$ & $\begin{array}{l}-0.055 \\
(0.100)\end{array}$ & $\begin{array}{c}-0.002 \\
(0.088)\end{array}$ & $\begin{array}{c}-0.050 \\
(0.089)\end{array}$ \\
\hline Incomplete college & $\begin{array}{c}-0.014 \\
(0.107)\end{array}$ & $\begin{array}{c}-0.050 \\
(0.108)\end{array}$ & $\begin{array}{c}-0.012 \\
(0.095)\end{array}$ & $\begin{array}{c}-0.041 \\
(0.096)\end{array}$ \\
\hline
\end{tabular}




\begin{tabular}{lcccc} 
Associate degree & 0.019 & -0.029 & -0.004 & -0.049 \\
Black & $(0.143)$ & $(0.144)$ & $(0.128)$ & $(0.129)$ \\
& 0.143 & 0.114 & $0.155^{*}$ & 0.126 \\
Hispanic & $(0.080)$ & $(0.080)$ & $(0.073)$ & $(0.073)$ \\
& 0.181 & 0.149 & 0.153 & 0.116 \\
Home owner & $(0.100)$ & $(0.101)$ & $(0.088)$ & $(0.089)$ \\
& -0.027 & 0.004 & -0.014 & 0.012 \\
Immigrant & $(0.062)$ & $(0.062)$ & $(0.055)$ & $(0.056)$ \\
& $-0.229^{*}$ & $-0.217^{*}$ & $-0.236^{*}$ & $-0.223^{*}$ \\
Contact employer & $(0.109)$ & $(0.110)$ & $(0.094)$ & $(0.094)$ \\
Contact public ea & & & & -0.018 \\
& -0.002 & -0.004 & -0.016 & $(0.057)$ \\
Contact private ea & $(0.063)$ & $(0.063)$ & $(0.057)$ & $0.127^{*}$ \\
& $0.188^{*}$ & $0.166^{*}$ & $0.144^{*}$ & $(0.065)$ \\
Contact friend/relative & $(0.070)$ & $(0.071)$ & $(0.065)$ & -0.059 \\
& -0.085 & -0.095 & -0.052 & $(0.097)$ \\
Contact school ec & $(0.109)$ & $(0.109)$ & $(0.097)$ & 0.136 \\
& 0.149 & 0.137 & 0.148 & $(0.077)$ \\
Sent resumes & $(0.083)$ & $(0.083)$ & $(0.077)$ & 0.018 \\
& 0.070 & 0.069 & 0.015 & $(0.151)$ \\
Check union & $(0.170)$ & $(0.170)$ & $(0.151)$ & $0.097^{*}$ \\
& $0.143^{*}$ & $0.138^{*}$ & $0.101^{*}$ & $(0.054)$ \\
Used ads & $(0.061)$ & $(0.061)$ & $(0.054)$ & 0.317 \\
& $0.395^{*}$ & $0.398^{*}$ & $0.322^{*}$ & $(0.165)$ \\
Other active & $(0.171)$ & $(0.172)$ & $(0.164)$ & 0.042 \\
& 0.049 & 0.050 & 0.041 & $(0.074)$ \\
Net access & $(0.080)$ & $(0.080)$ & $(0.074)$ & -0.087 \\
& -0.074 & -0.062 & -0.104 & $(0.119)$ \\
Log likelihood & $(0.137)$ & $(0.137)$ & $(0.119)$ & $-0.239^{*}$ \\
& & & & $(0.071)$ \\
\hline
\end{tabular}

\section{Notes:}

1. Following the specification in equations (1) and (2), and in contrast to Table 4, a positive coefficient now means the variable in question is associated with a longer duration of unemployment.

The sample size for all specifications is 4139 . 
Table 6: Bivariate lognormal duration models with length-biased sampling correction.

\begin{tabular}{|c|c|c|c|c|c|c|}
\hline & \multirow{2}{*}{\multicolumn{2}{|c|}{$\begin{array}{c}\text { No endogeneity } \\
\text { correction }(\rho=0)\end{array}$}} & \multicolumn{4}{|c|}{ With endogeneity correction ( $\rho$ unconstrained) } \\
\hline & & & \multicolumn{2}{|c|}{ Instrument Set 1} & \multicolumn{2}{|c|}{ Instrument Set 2} \\
\hline & $(1)$ & $(2)$ & $(3)$ & $(4)$ & $(5)$ & $(6)$ \\
\hline Net search & $\begin{array}{c}0.051 \\
(0.050)\end{array}$ & $\begin{array}{l}0.184^{*} \\
(0.057)\end{array}$ & $\begin{array}{l}-0.303 \\
(0.426)\end{array}$ & $\begin{array}{l}-0.036 \\
(0.466)\end{array}$ & $\begin{array}{l}-0.147 \\
(0.696)\end{array}$ & $\begin{array}{l}-0.309 \\
(0.425)\end{array}$ \\
\hline Net access & & $\begin{array}{l}-0.202^{*} \\
(0.083)\end{array}$ & & $\begin{array}{l}-0.118 \\
(0.202)\end{array}$ & & $\begin{array}{l}-0.004 \\
(0.201)\end{array}$ \\
\hline Rho & 0 & 0 & $\begin{array}{c}0.207 \\
(0.240)\end{array}$ & $\begin{array}{c}0.127 \\
(0.262)\end{array}$ & $\begin{array}{c}0.111 \\
(0.401)\end{array}$ & $\begin{array}{c}0.282 \\
(0.223)\end{array}$ \\
\hline Log likelihood & -3784.89 & -3463.61 & -3784.65 & -3463.49 & -3795.74 & -3477.02 \\
\hline
\end{tabular}

Note: Standard errors are in parentheses. ${ }^{*}$ indicates significance at the $5 \%$ level. The sample size for all specifications is 4139 . 


\section{IZA Discussion Papers}

\begin{tabular}{|c|c|c|c|c|}
\hline No. & Author(s) & Title & Area & Date \\
\hline 596 & $\begin{array}{l}\text { H. Görg } \\
\text { E. Strobl }\end{array}$ & $\begin{array}{l}\text { Relative Wages, Openness and Skill-Biased } \\
\text { Technological Change }\end{array}$ & 2 & $10 / 02$ \\
\hline 597 & $\begin{array}{l}\text { S. M. Fuess, Jr. } \\
\text { M. Millea }\end{array}$ & $\begin{array}{l}\text { Disentangling Pay and Productivity in a } \\
\text { Corporatist Economy: The Case of Germany }\end{array}$ & 5 & $10 / 02$ \\
\hline 598 & $\begin{array}{l}\text { D. Del Boca } \\
\text { A. Lusardi }\end{array}$ & $\begin{array}{l}\text { Credit Market Constraints and Labor Market } \\
\text { Decisions }\end{array}$ & 2 & $10 / 02$ \\
\hline 599 & $\begin{array}{l}\text { H. N. Mocan } \\
\text { B. Scafidi } \\
\text { E. Tekin }\end{array}$ & Catholic Schools and Bad Behavior & 5 & $10 / 02$ \\
\hline 600 & $\begin{array}{l}\text { J. S. Lauerová } \\
\text { K. Terrell }\end{array}$ & $\begin{array}{l}\text { Explaining Gender Differences in Unemployment } \\
\text { with Micro Data on Flows in Post-Communist } \\
\text { Economies }\end{array}$ & 4 & $10 / 02$ \\
\hline 601 & $\begin{array}{l}\text { Š. Jurajda } \\
\text { K. Terrell }\end{array}$ & $\begin{array}{l}\text { What Drives the Speed of Job Reallocation } \\
\text { during Episodes of Massive Adjustment? }\end{array}$ & 5 & $10 / 02$ \\
\hline 602 & L. Locher & Migration in the Soviet Successor States & 2 & $10 / 02$ \\
\hline 603 & $\begin{array}{l}\text { T. Andrén } \\
\text { B. Gustafsson }\end{array}$ & $\begin{array}{l}\text { Income Effects from Labor Market Training } \\
\text { Programs in Sweden During the 80's and 90's }\end{array}$ & 2 & $10 / 02$ \\
\hline 604 & $\begin{array}{l}\text { S. P. Jenkins } \\
\text { C. Schluter }\end{array}$ & $\begin{array}{l}\text { The Effect of Family Income during Childhood on } \\
\text { Later-Life Attainment: Evidence from Germany }\end{array}$ & 5 & $10 / 02$ \\
\hline 605 & C. Grund & $\begin{array}{l}\text { The Wage Policy of Firms - Comparative } \\
\text { Evidence for the U.S. and Germany from } \\
\text { Personnel Data }\end{array}$ & 5 & $10 / 02$ \\
\hline 606 & $\begin{array}{l}\text { M. Gerfin } \\
\text { M. Lechner } \\
\text { H. Steiger }\end{array}$ & $\begin{array}{l}\text { Does Subsidised Temporary Employment Get } \\
\text { the Unemployed Back to Work? An Econometric } \\
\text { Analysis of Two Different Schemes }\end{array}$ & 3 & $10 / 02$ \\
\hline 607 & Y. Zenou & How Do Firms Redline Workers? & 5 & $10 / 02$ \\
\hline 608 & G. Saint-Paul & $\begin{array}{l}\text { Economic Aspects of Human Cloning and } \\
\text { Reprogenetics }\end{array}$ & 3 & $10 / 02$ \\
\hline 609 & G. Saint-Paul & Cognitive Ability and Paternalism & 3 & $10 / 02$ \\
\hline 610 & A. Heitmueller & $\begin{array}{l}\text { Unemployment Benefits, Risk Aversion, and } \\
\text { Migration Incentives }\end{array}$ & 4 & $10 / 02$ \\
\hline 611 & G. Saint-Paul & $\begin{array}{l}\text { Some Thoughts on Macroeconomic Fluctuations } \\
\text { and the Timing of Labor Market Reform }\end{array}$ & 3 & $10 / 02$ \\
\hline 612 & $\begin{array}{l}\text { J. J. Dolado } \\
\text { M. Jansen } \\
\text { J. F. Jimeno }\end{array}$ & $\begin{array}{l}\text { A Matching Model of Crowding-Out and On-the- } \\
\text { Job Search (with an Application to Spain) }\end{array}$ & 2 & $10 / 02$ \\
\hline 613 & $\begin{array}{l}\text { P. Kuhn } \\
\text { M. Skuterud }\end{array}$ & $\begin{array}{l}\text { Internet Job Search and Unemployment } \\
\text { Durations }\end{array}$ & 5 & $10 / 02$ \\
\hline
\end{tabular}

